\title{
EIEVATION OF THE DIAPHRAGIF.
}

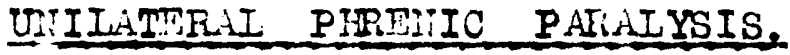

\section{A RADIOLOGICAI STUDY, HITH SPECIAL REFEREICE}

IO THE DIFHEREITIAL DIAGNOSIS.

J. M. WOODBURN MORISON, M.B., C.M.

Hon. Asgistant Radiologist, Rojal Infirmary ilanchester.

Iecturer Applied Anatoris - Raciiological. Wanchester University. 
ProQuest Number: 13915844

All rights reserved

INFORMATION TO ALL USERS

The quality of this reproduction is dependent upon the quality of the copy submitted.

In the unlikely event that the author did not send a complete manuscript and there are missing pages, these will be noted. Also, if material had to be removed, a note will indicate the deletion.

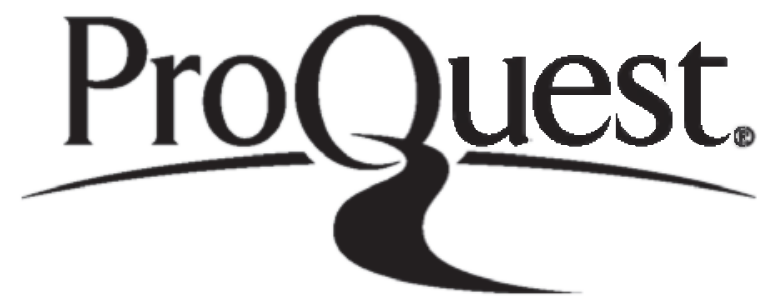

ProQuest 13915844

Published by ProQuest LLC (2019). Copyright of the Dissertation is held by the Author.

All rights reserved.

This work is protected against unauthorized copying under Title 17, United States Code Microform Edition (C) ProQuest LLC.

ProQuest LLC.

789 East Eisenhower Parkway

P.O. Box 1346

Ann Arbor, Ml $48106-1346$ 
Sean Lous Petit

Bown manch 13.. 1674

Died April 1760

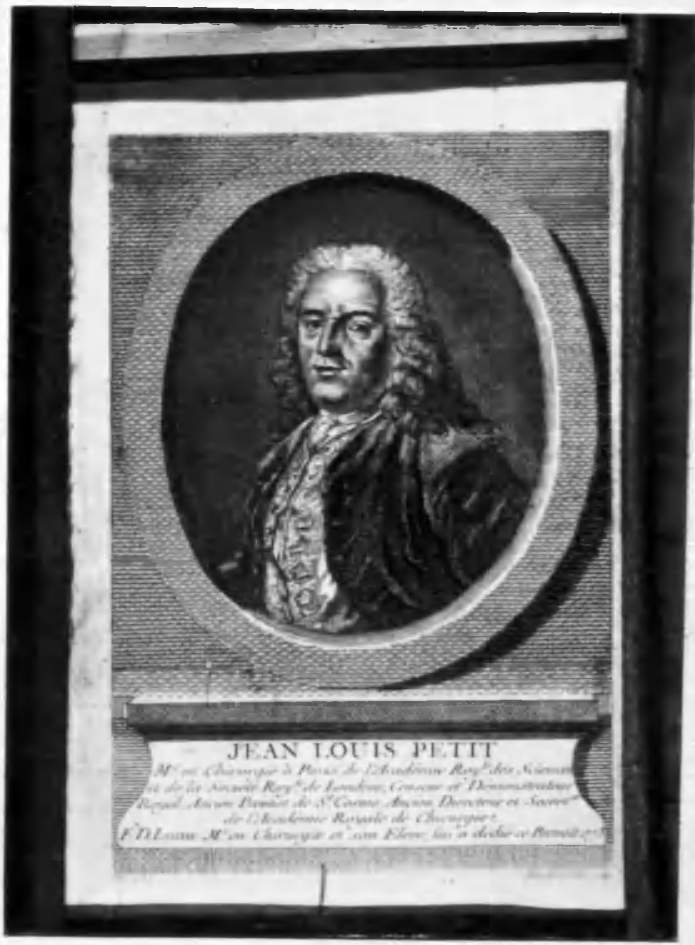

The witings of fean Drmis Pefit wre collected and fublished after his death by his infill Lesne.

The secretary of the Academice des deiences of the mstitut de France wites "f'ai l'homewr de vous faire comnaitre que, d'apies les recherches que nons arons hue faire, il semble que ce mémoire ría jamais ite fublicé du vivant de fean Lous Pefit mais il est dans les 3 edifions de ses veurves hosthowmes de 17Y4, 1980, 1990." 


\section{ELUVATION OF TEE DIAPERAGM.}

\section{UNILATERAL PHBEAIC PARALYSIS. by. .}

J. 4. WOODBURH KORI SON, K.B.

My thesis is malniy a radiological study of Blovation of the diaphrapm with some observations on the differentlal diagnosis. I have added to the titlo that of Unilateral phrenic paralysis for two reasone: flrstly. I hope to ghow during the courge of this paper that oertain forms of congenital elevation of the diaphragm are probably due to a unllateral phrenio peralgsis, and socondly, to prosent for conglderation a nuber of oager in which paralyolo of one or other leaflet of the diaphraem was oased by a definite pathological lesion involving the phrenio norre in 1 te paseago through the thorax.

Blevation of the diaphragm may be pormanent or temporary, and permanent olerations maj bo oomgenital or aoquired.

Und or the hoading Pormanent elovation of the dlaphragm wo may place Petit's "orentratlo dephragmatican and also those oases which I shall describe later of unilateral phronic paraljsis. 
It is noual in writing of elevation of the diaphragm to begin by stating that "Potit in 1790 described a diffuse relaxation of the diaphragm" or again "Eventration of the diaphragm has been known ever sinoe J. I. Petit reported and named a case in 1790." Many of the writers on thia aubject have done so. This is unfortunate because Jean Louls Petit died in April 1760 at the age of 86 jears. His writings were collected and published by Lesne, his pup11, in 1774, 1780 \% 1790.

J. I. Petit, one of the most brilliant French surgeons of the 18th. century, was the first to clearly differentiate the condition known as Bventratio Diaphragmatica from the ugal Diaphragmatio Hernia.

In his writings ne states that he has seen two

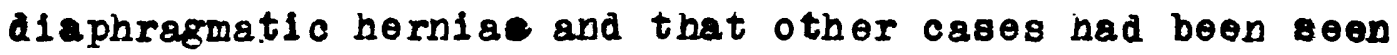
by several of his colleagues. He recognised that congenital defects occurred in the diaphragm and noted the absence of a hernial sao in the first case he recorded. He also commented on the faot that both the hernias of tho diaphragm which ho had soen were on the left side. His confrères told him that all those which they had seen were likewise on the left side. This led him to suggest that the convex sarface of the liver protects the right side of the diaphragm. 
The two oases which he desoribed were in adult males, and clinioalig of long standing.

The first case was one of true diaphragmatic hernia in which, at the post mortem, a great part of tho stomach, a portion of the colon and part of the omentum had passed through a defeot in the dorsal part of the left diaphragm into the thorax. There was no hernial sac and there were no adhesions.

The second case was also on the loft side, and Petit stategthat he considered it to bea congenital abnormality. At the post mortem, on opening the chest he found a tamour, the size of "a small gourd". formed by a portion of the stomach, colon and omentum, and encloged in a hernial sao which was formed by peritonoum, diaphragm and pleara. 4 "thick lymph" of recent origin had censed adberions to the lower lobe of the lung, and the contents were similarIf held together, so that when removed from the sao they kept the shape of the whole tumour.

The death of this patient was attributed to "Inflammation of the Abdomen".

It is thus seon that Petit clearly recognised that h1s second ease was of a different type from the usual diaphragmatio hernia, and to it he gave the name "Brentratio Diaphragmatiog". Since his time Jo cases havo boen recorded. In the oarly days it was a thological 
desoription, bat einoe the introduction of $\mathrm{X}$-rays to the study of mediolne, and more especially of recent years with the advance of radiology, it has become possible to acourately observe and dignose these cases during life. 
I shall flrst describe 6 osses which I have classified as Bventratio Diaphragmatioa. Group 1.

In group 2. I record a series of cases of Unilateral Phrenio Paralysis which I think throw a good deal of light on the aetiology of group 1.

The follows a short note on Temporary Elevation of the Diaphragm with illustrative oases. Group 3. The differential diagnosis from oases of diaphragmatic hernia - group 4. - and from other conditions such as looelised hydro or pyopneumo thorax and subphrenic abscess w111 also be consi dered. Group 5.

Finally I shall discuss the aetiology and the literatare and give my conolusions. The Bibliography is attached.

It will aleo be necessary to make some observations on the anatomy and action of the normal diaphragm during the course of this paper. 


\section{Eventrat10 Diaphragmatica.}

It is generaliy accepted that the term, Eventratio Diaphragmatica, should be applied to those cases of oongental origin in which there 18 a diffuse relaxation of one half of the diaphragm so that it extends high up into the thorax forming a sac which contains a portion of the stomach, and sometimes a part of the colon and mesentery. All the cases recorded have been on the left side with the exception of one by Eppinger in 1911.

In these cases physical examination may determine varying and anomalous signs at the base of the left homithorax and also an alteration in the position of the hoart, but the radiological examination makes it posalble to interpret these signs and arrive at a correct diggnosis.

In the radiological examination the following pointe require consideration:-

1. The bow line in the chest.

Th1s is present in all cases as an unbroken line extending across the left nomlthorax. Sometimes it is slightly irregular on account of the colon lying alongside the air sac of the stomach, a different pressare of gas in the colon from that in the stomach accounting for the sight 1 rrogularity. This bow line enoloses an air 
Plate 2

Eventratio Diaphragmatic.

Group I.

base 1.

a. OB. girl. aged 12 years.

Chest. upright position - Post ant.

Note the bow lime in the chest, horizontal line of free fluid in stomach to. 
Plate 3 .

Eventratio Diphtregmatica

Group I

Case 1.

a.' OB. girl. aged 12 years.

Stomach. upright position. Post ant.

After a Bismuth meal. 
space at the bottom of which there is often seen the sharply defined horizontal line of free flutd in the atomach. The whole forms a dome in the chest and presents a striking picture.

2. Contents of the dome.

The air 820 of the stomaoh is alwaye present and may ocoupy the whole of the dome. At times a portion of the colon may be found lying alongside it.

3. Lung tisgue seen through the dome.

In the cases which I have investigated I have noted that lung tisave was seen through the upper part of the dome.

4. Movements of the bow 1ine.

It is usually stated that no movements of the bow Iine, (the relaxed, thinned out diaphragm) ocour, or if ang movements were observed, that they were synchronats with the normal leaflet.

In all my cases I observed reversed movements, but in one case only after adhesions to the lung uad been divided and until they reformed.

5. Level of the stomaoh contents.

The level of the stomach contents is always the level of the cardiac orfifoe.

6. Palpation of the abdomen.

splashing and rippling on the surface of the fluid in 
Plate A

Bventratio Diaphragmatic

Group I

base 1.

a. O'B. gink. aged is years.

Stomach. Upright position Oblique view. hole the two sacs - the upper spilling forwards into the lower. 
the stomach is easily produced by palpation of the abdomen.

7. The shape of the stomech.

Deformity. of the stomach frequently ocours. It is due to the ascent of the greater curvature of the stomach under the elevatid diaphragm, with rotation on more or less fixed points. The stomach presents two sacs, the upper spililing forwaris into the lower. The rotation maj be so great that a volvulus is produced which may require sumioal interference. In man of the cases reco rded there is a history of stomach trouble.

8. Displacement of the heart.

Part of the heart shadow is usually seen through tho air in the dome. The heart may be displaced to the right and in some of the oases recorded this has evidently beon a marked feature.

9. Movements of the chest wall.

No difference in the movements of the two sides of the chest were detected in the cases which oame under my observations. 
Eroup I

base 1

A. O'B. girl aged 13 years.

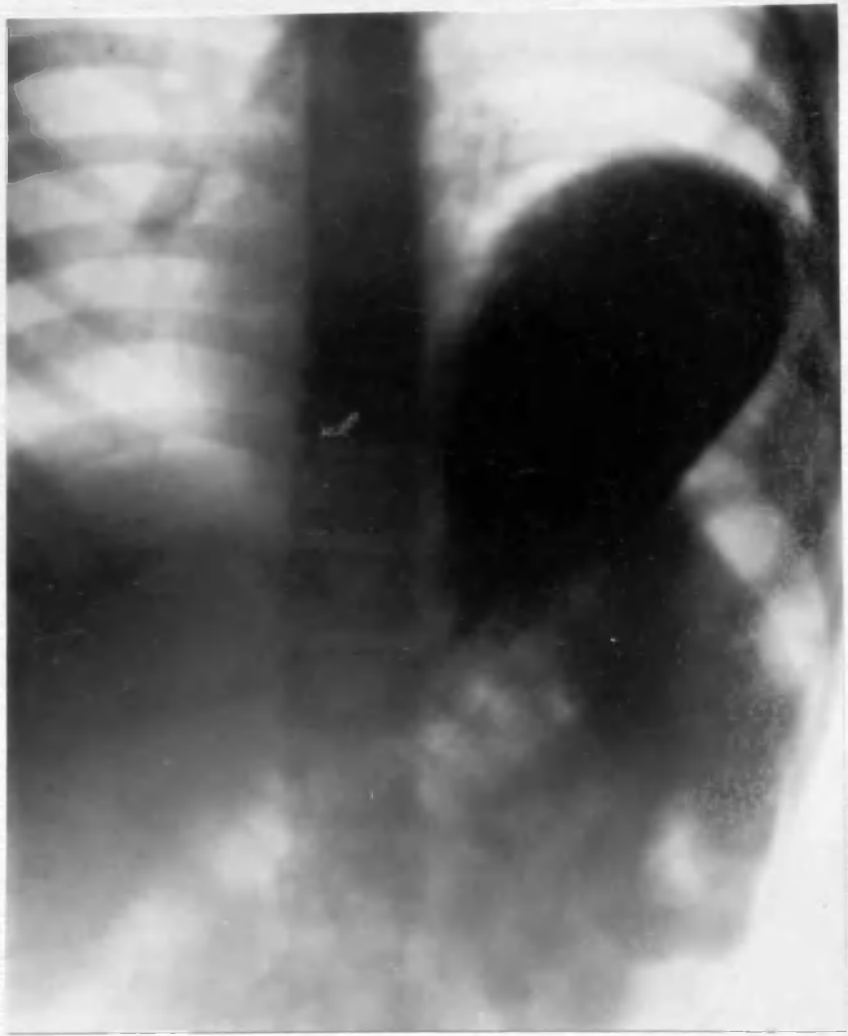

Stomach. Patiuct lying down.

hote. the conteuts of the stomach have replaced the air in the air sac and exteud high up ielo the chest, but not beyond the bow live. 
Group I. Bventratio diaphragmatioa.

Case 1.

In January 1920 a school girl A. O'B. aged 12 years, was brought to hospital having had a cold and cough for two weeks.

The familg history was unimportant and there was nothing to suggest the condition found at the $X-r a y$ examination.

The ecreen examination of the chest showed a complete regular dome on the left side, extending as igh as the level of the $3 \mathrm{rd}$. rib in front and onclosing an air space through whioh in the uppor part lung tissuo was seon. At the bottom of this air apace there was a sharply defined horizontal line of fluid on which waves and ripples were produced by palpation of the abdomen.

No definite morements of the bow Iine in the chest were observed during respiration, although on one oceasion I though there was a slight reversed movement, an upward movement during inspiration and a downward movement during expiration, bat I was not quite confident of this.

The dome of the right diaphragm was at the level of the 10th. dorsal vertebra. Its movements were normel. The heart was sligntly displaced to the right. 
Plate 6

Eventratio Diaphragmatica.

Eroup I

base. I.

a. O'B girl. aged 13 years

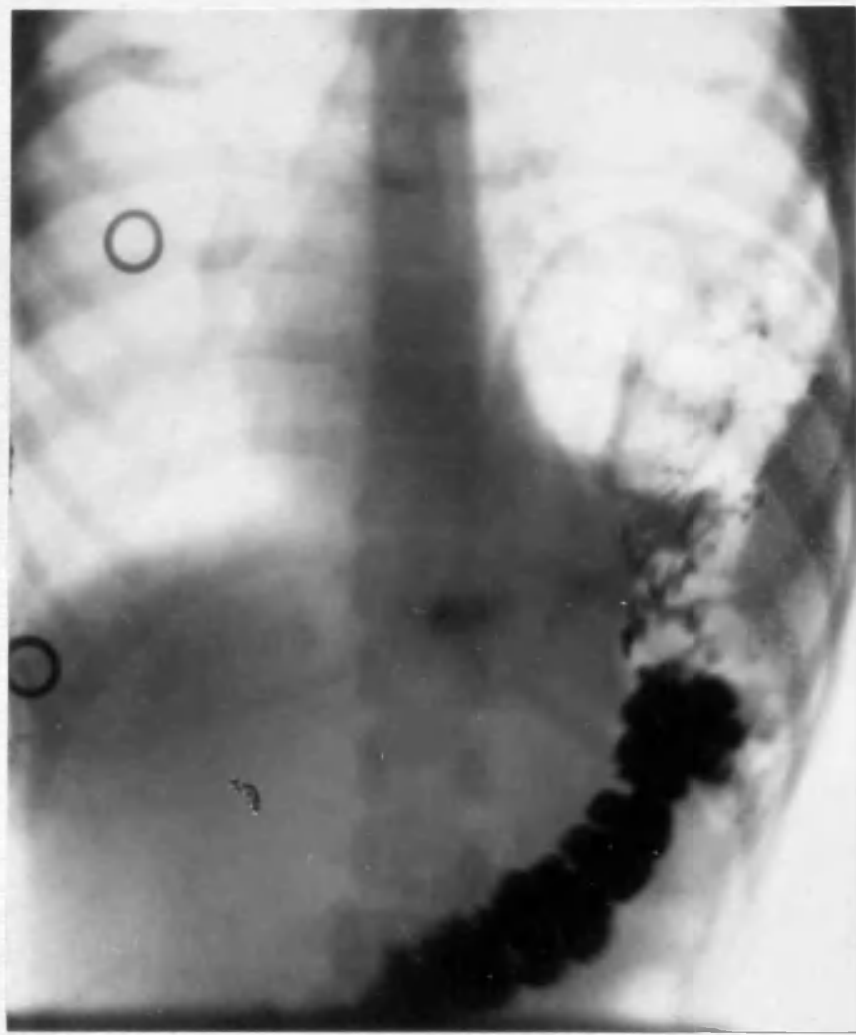

bolon.

Paticut lying down.

Bismuth food in colon which exteuds up under the bow live, where a few flates of the food cau be seen. 
There was an increased density of the root ahadows of both lunge.

On giring a bismuth moal the food was hold up at the cardisc opening of the oesophagas, the lower third of which was dilated, the obstruetion was soon overoome and the atomach was oeen to 1111 in an Irrogular manner. The caves of this was apparent when the patient, who up to this stage had boen examined in the postero-anterior position, was placed in the right anterior oblique position There were two sacs, the shadows overlapping in the postero-anterior position. The upper sac, when filled, spillod in a forward direction into the lower.

The pyloric ond of the stomach was directed backwarde and was not well formed.

There was no delay in emptying.

In the lying down position the bismuth meal passed up to the top of the bow In in the chest, af splaoing the air and completely flling the dome which was not altered in position.

Nothing abnormal was detected in the small intesti ne. The colon was well outlined and the splenic flexure was found to rise alongside the air cap of the stomach to the top of the bow line in the cheat, but not beyond 1 t. At other times the whole of the dome in the chest wes fillod 
$\frac{\text { Plate y }}{\text { Eventratio Diaphragmatica. }}$

Group I

base 1.

a.0'B. girl aged 's years.

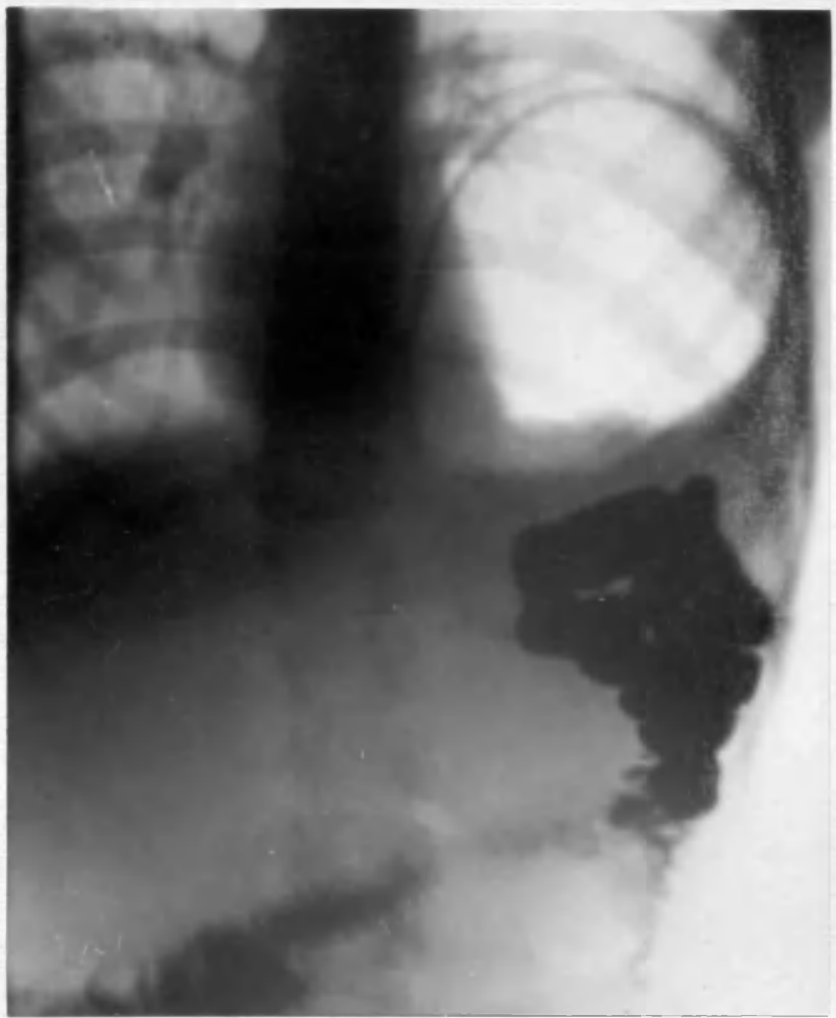

bolon

Bismuth food in the splevie flexure. hote that the colon is not forming part of the conteuts of the dome. 
by the els opp of the etomech.

A Barim encas confl rwed these obeervatione on the color whl oh was otherwise normal.

jis wes erideatly a case of Petit's Broptratio Di aphragmat1 oa.

Mr. John Yorley, F.R.C.S., operated by the thoraolo route, and from his notes I have extraoted the following:"The fundus of the stomaon was seen projecting ap into the thorax far above the level of the incision. It was at once apparent that a transparent layer of thinned out diaphragm formed a covering for the - lorated abdominal viscera and separated thom completely from the true pleural oafity. To the highest point of this thin translucent diaphragm the base of the left lung was firmly adherent. These adhest ons were fibrous and vascular, and were readily divided. The diaphragmatio sac was now incisod. on opening it the splenic flexare of the colon and left extremity of the great omentum and the greater ourvature of the stomach were presented. These were quito froe from adhesions. The upper polo of the apleon also came into viow. The whole diaphragm was merely represented by a thin sheet consisting of pleura above and peritoneum below with some rather 
Peate 8

Bventiatio Diaphraematica.

Eroup I

basel.

Q.0.B. girl. aged loges

bhest sprightposition. Post aut. (Thre years later.) kote bow live in chest. 
Peate 9

Erentratio Diaphragmatica.

Eroup I

base 1.

a.0.B. girl aged. 16 yos
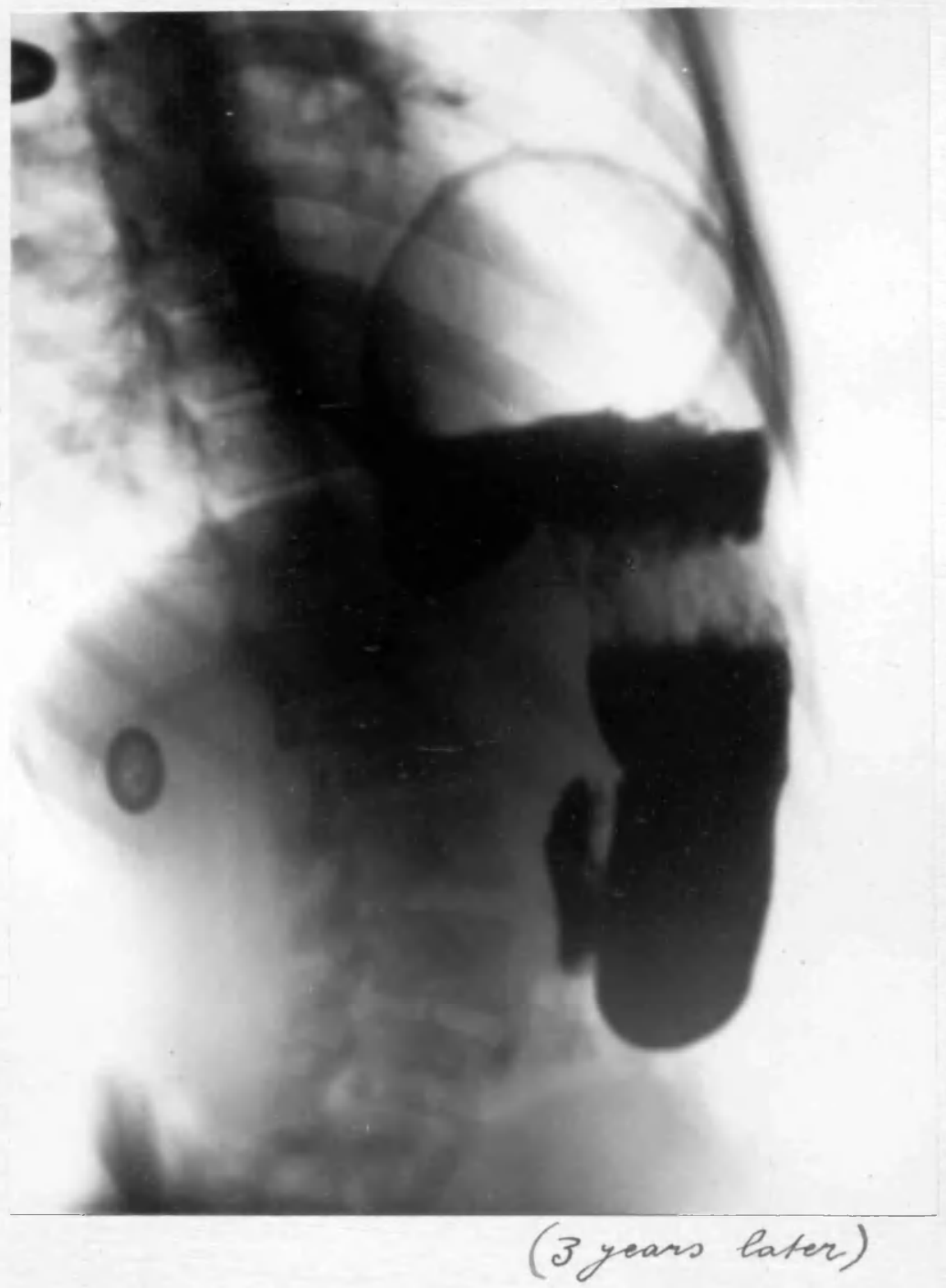

Stomach.

Oblique vieur after a brismuth meal. hote the deformily of the stomach. 
dense fibrous tissue between.

A partial excision

of this diaphragmatio 820 was determined upon with the object of bringing down its level as near to the normal as posilble and so reducing the distortion of the stomach and allowing more expansion of the lungs.

Convalescence was uneventful and rapid.

Pour wooks after the operation I made another X-ray examination of this oase.

The lung was fully expanded, the bow line in the chest was not so high, its movements were quite free but reversed, and the stomach presented a more normal appearance, the exaggerated cup and spill formation having disappeared. Subsequent examinations showed thet the movements of the bow Iine become less and less free, finally no movements were observed, adhesions having oridently re-fomed.

Mioroscopical sections of the pleoe of diaphragm remored showed normal endothelium on the pleural and peritoneal eurfaces and between these, dense fibrous tissue with no sign of arucle fibres. No nerve fibres could be made ont in sections that were speoially stained to show them.

Three joars later I took the opportunity of again examining this case - January 1923. The condition was 
found to be much the eame as at the last examination. She suffers no incontenience and is engaged in house work.

Case 2.

The second case was a man, B.K. aged 54, who was operated on for pyloric obstruation. At the operation 1t was found that the left half of the diaphragm extended high up into the chest, and that the obstruction was due to a torsion of the stomach. This was relieved. I had the opportunity of $X$-raying this man some monthe later: The screen examination showed the bow line of the elevated left diaphragm rising up into the chest, the Iine was continuous across the left hemithorax, but not perfectly regular, as both the air sao of the stomach and the splento flexure could be distinguished, the different degreos of pressure in the two causing a slight irregularity. Some lung tissue could be seen through the upper part of the dome. The horizontal line of fluid in the stomach was observed, but this extended only part of the way across the left chest. Fall, freo revereed movements of the diaphragm were noted. Palpation of the abdomen produced waves along the line of fluia. On giving a Bismuth meal the stomach was seon to be of the "cup and apilin typo. There was no delay 
Tlate 10

Eneutratio Diaphragmatica.

Group I

base 2 .

B. K. Mnale. agedskyes.

bhest. Epright position. Post aut. hote elevated diaphragm. 
in emptying. In the lying down position bismuth food filied up the space under the bow Iine in the chest ocoupied by the air sac, and during subsequent examinations the eplenic flexure was seen outlined by bismuth. This was evidently a true case of eventration of the diaphragm in which there were no symptoms untif the onset of a pyloric obstruction due to an increased rotation cansing a volvulus. At the present time this man is in good health and suffers no discomfort.

The third case was a married woman.

Case 3. Mrs. M. H. aged 48 years.

This case was sent for X-ray examination of the chest. It was noted that the oardiac dulness was displaced to the right, this being the only definite physical sign. She complained of indigestion extending over a period of three jears with occasional and romiting. There was no acute pain but often a feoling of discomfort after food.

The $\mathrm{X}$-ray examination showed a regular and typical dome shaped elevation of the left diaphragm through which some lang tissue could be seen in the upper part. It rose to the level of the $3 \mathrm{rd}$. rib in front. The horizontal Iine of free fluid in the stomach was present, and the whole of the spece beneath the dome at the first examinatio. 
Plate II

Eventratio Diaphragmatica.

Group I

base 3.

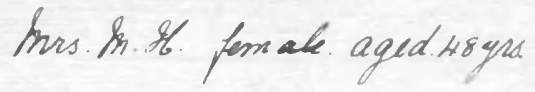

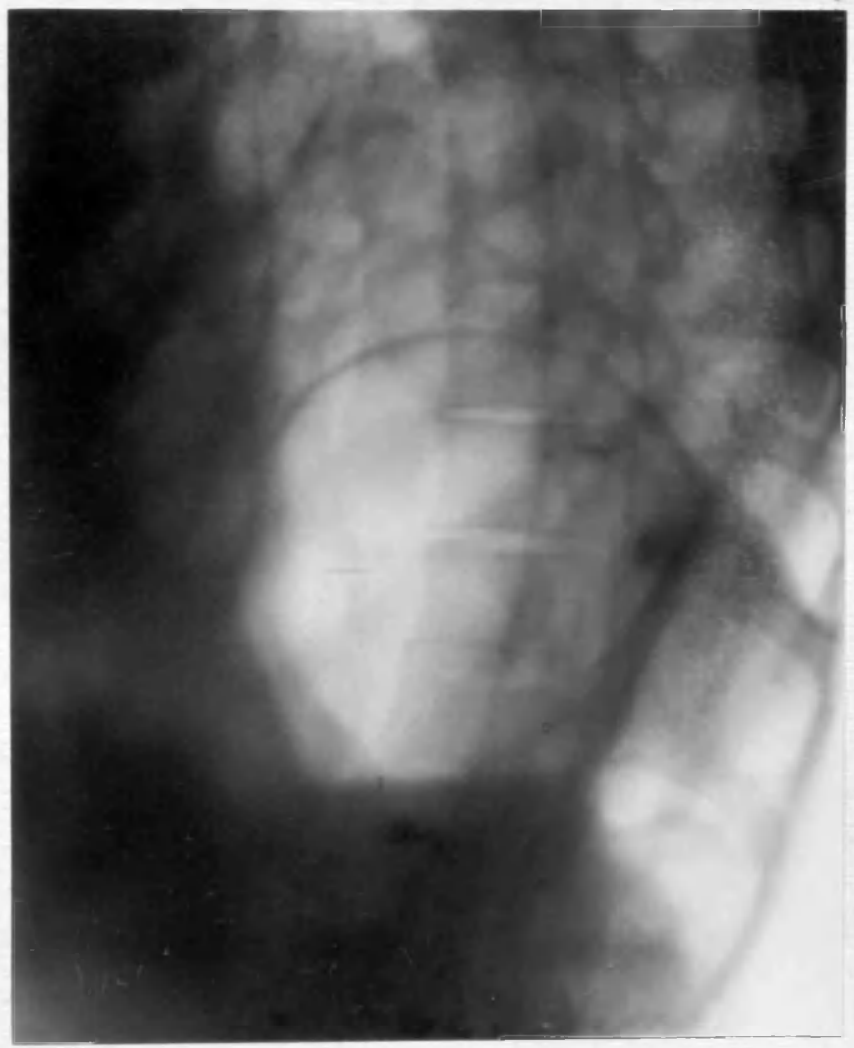

bhest Eprightposition - lateral vicews.

Note- Glevated diaphragm 
was occupled by the air sac of the stomach. At other times the splenic flexare was seen to be rising up alongside the stomach under the dome, but it was not always present. There were complete and free reversed movements of the left half of the diaphragm.

on giving a Bismuth meal the usual deformity of the 8 tomach was found although it was not so marked in this case as in some of the others.

She still ouffers from indigestion and evidently from an intermittent obstruction due to drag on the pylorue from mechanical causes.

Case 4. H. B. Aged 41 years.

This man was sent to ser me in December 1922. For the pest 20 years he had suffered from indigestion. The attacks were intermittent, gradually becoming worse. Dr. Pldalan, of Ashton-under-Lyne, his medical attendant etates "He had, on December 15th., an achte attack of opigastric pain with vomiting. I had great difficulty in getting the bowels mored and the stool finally was green and offengive. He has been well purged since, starved for 48 hours and then fed carefully but his pain does not wholly alsappear, it comes on two hours or so after food and wakes him up in the night."

4 bismuth meal was given and a soreen examination revealed condition similar to those oases already 
$\frac{\text { Plate } 12}{\text { Eveutratio Diaphragmatica. }}$

Sroup T

base 4

If. B. male aged wi geans

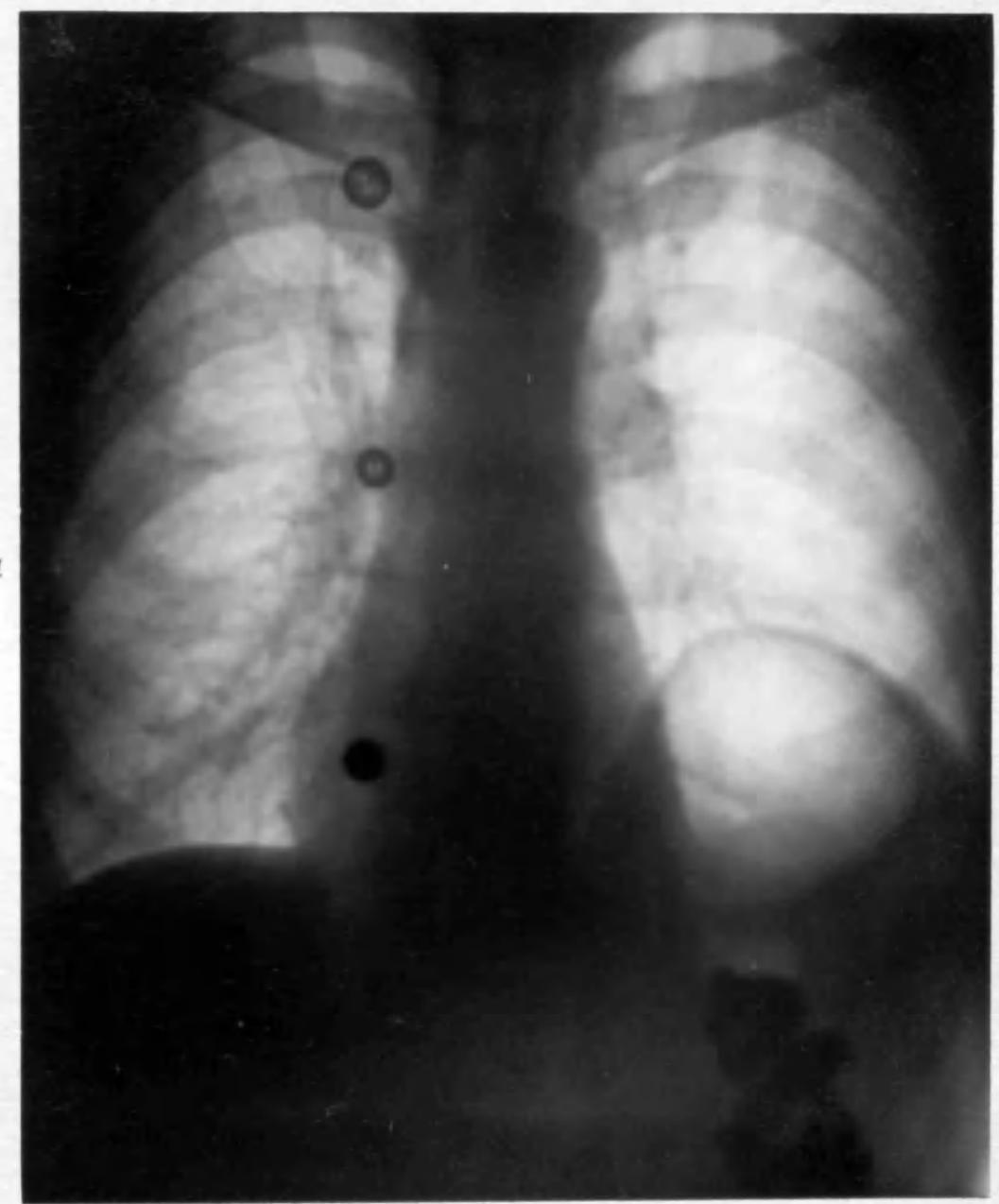

bhest spreght position. Post aut.

note elevated diaphragm. 
Peate 13

Eventratio Diaphragmatica.

Eroup T

base 4.

I6. B. hale aged HI years

Stomach. After a bromuth meal. Post aut. 
Peate 14.

Eveutratio Diaphragmatica

Erouf I

base'4.

86. B. male aged hi years

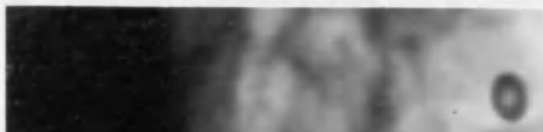

Stomach. Epright position. Oblique vieus. after bismuth meal. Kote deformily of stomach 
Eveutratio Diaphragmatica.

Group T

base. 4 .

H. B. male aged ki yeass

bolon Patieut in lying down position. kote the preseuce of the colon which is outlued by bismuth. 
desoribed. The left leaflet of the diaphragm was raised and its movements reversed. It presented an unbroken line etretohing acrose the left bemithorax. Through the dome lung tisgne was seon and it was noted that sometimes the colon rose up alongside the alr eap of the stomach under the done. Onoe again the typioal deformity of the stomach was present.

Case 5. S.K. Aged 39 Jears. A stone guarry man.

He had suffered from stomach symptoms during the past 5 joare. They wore of an intermittent charaoter. Ho had pains 2 to 4 hours after food which were relieved by taking more food. He often suffered from sickness and retching but never vomited. In writing to me, Dr. Lynch of Hayfield 8ay8, "About three months ago I was called to see him during the night. He was suffering acutely, the upper half of his abdomen was very temder. The pain came on very suddenly and ateadily grew woreo. The clinical pioture was suggestive of perforation. As the attack occurred during the nignt I gave him a hypodermio of morphia and was quite surprised when I saw him early next morning to find him perfectly well".

Here again I found the characteristic picture already describod, the left diaphragm elevated, etc. 
Eventratio Diaphragmatica

Sroup I

base. 5.

S. K. male

aged 39 , years

lehest. Bprightposition. Post aut kote bow live in chest 
Peate 1y

Eventratio Diaphragmaticic

Group I

Gase s.

SK. male

aged iq years

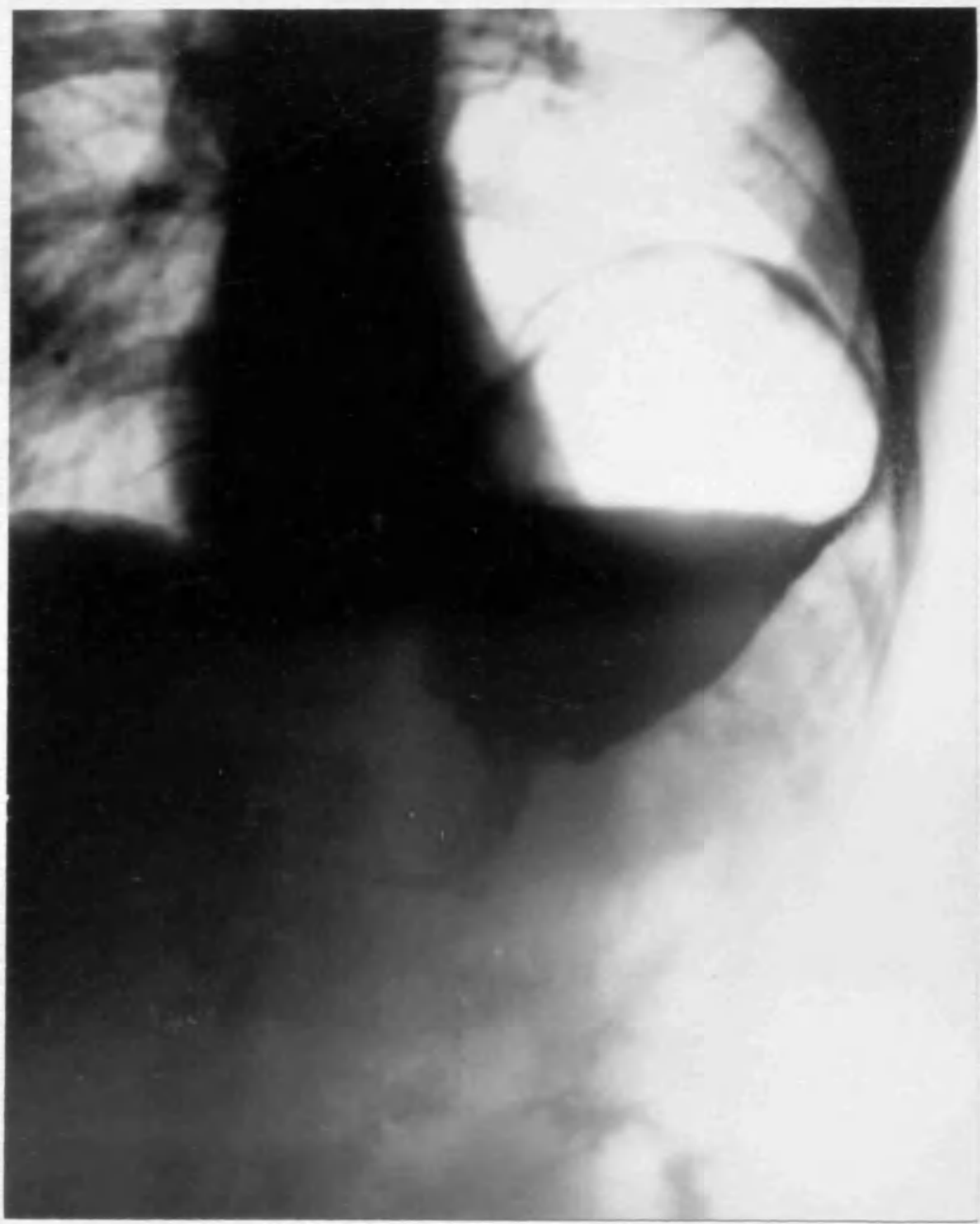

Stomach. Epright position.

after biomuth meal 
Plate 18

Eventratio Diaphragmatic

Group I

base. 5:

ST. male aged dis years

bolton. Patient in lying down position All the air has not been displaced from the dome which is not fully outlined by the bismuth food 
Case 6.

The 81xth and last cose which I have seen came to the Manohester Royal Infl rmary in January of this year 1923. J. B. a labourer, aged 51 years. He stated that he was perfeotly well untll about a month ago when he developed a bad cold. Suddenly he was seized by a pain in the stomach, wes sick but could not romit. Since then he has had difficulty in swallowing solld food but no difficulty with liquids.

A bismutn meal was taken wi thout much trouble, and it was noted that there was some delay at the cardiac oritice of the atomach, the unbroken bow line of an elovated left diaphragm was seen exterding well up into the chest. Its movements wero reversed, the typical deformity of the stomach and all the other radiographic features common to these oses were noted.

It is probable that these cases are muoh more common than is usually supposed and the individual may go through Iife whout suffering much disoomfort.

Yoat of the cases recorded have been in adults. Frequently the digplacoment of the heart to the right found in the course of the olinical examination is the reason for the patient being sent to the radiologigt for further investigation, but more often it is the presence of indefinite gastric symptoms. 
Peate 19.
iratio Diaphragmatica.

Sroup I

base 6.

4. B. male
aged st years

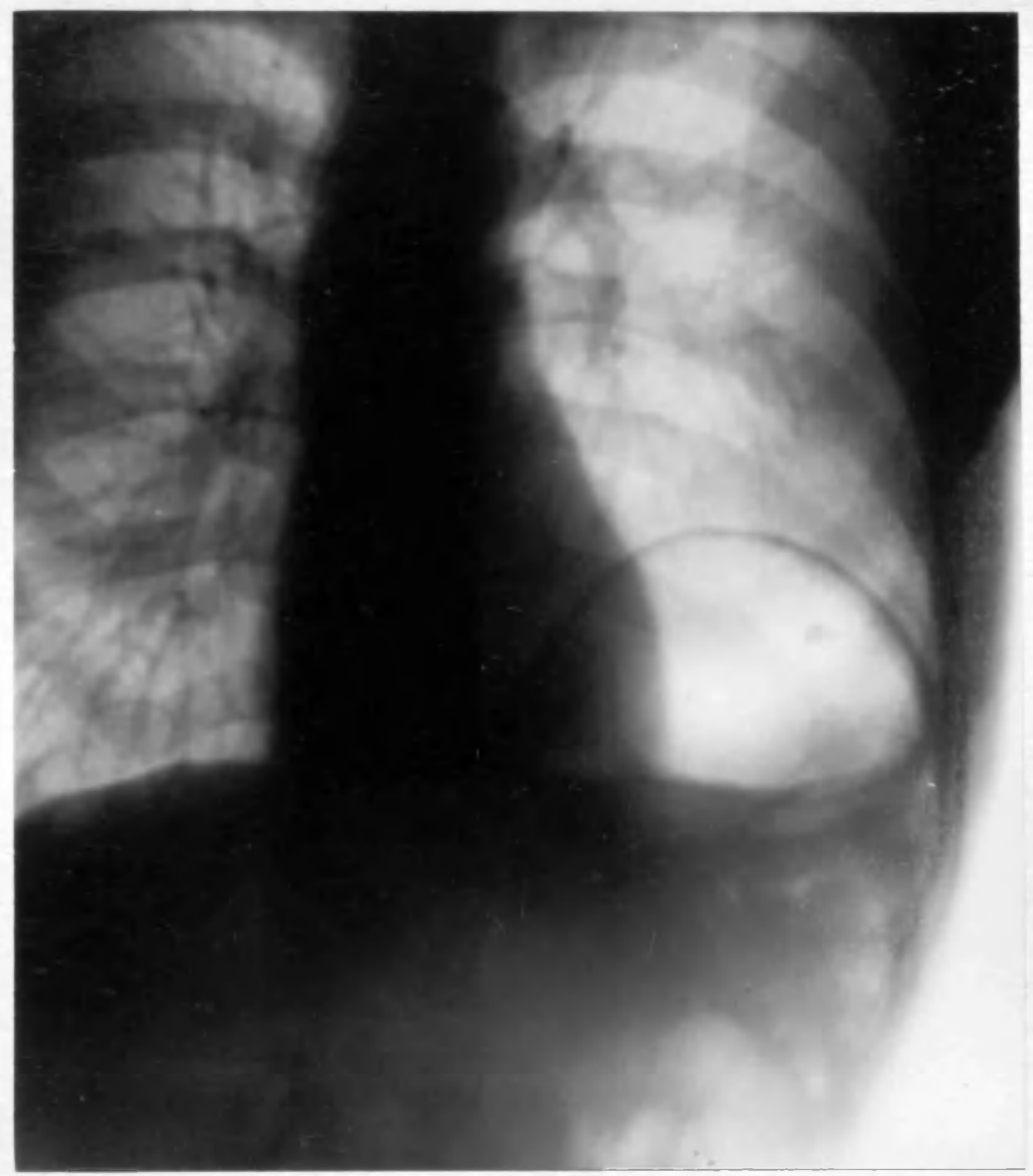

bhest.

sprightposition. Post aut hote bowline in chest. bolon not present. 
Group T base 6

f. B. male aged sy yean

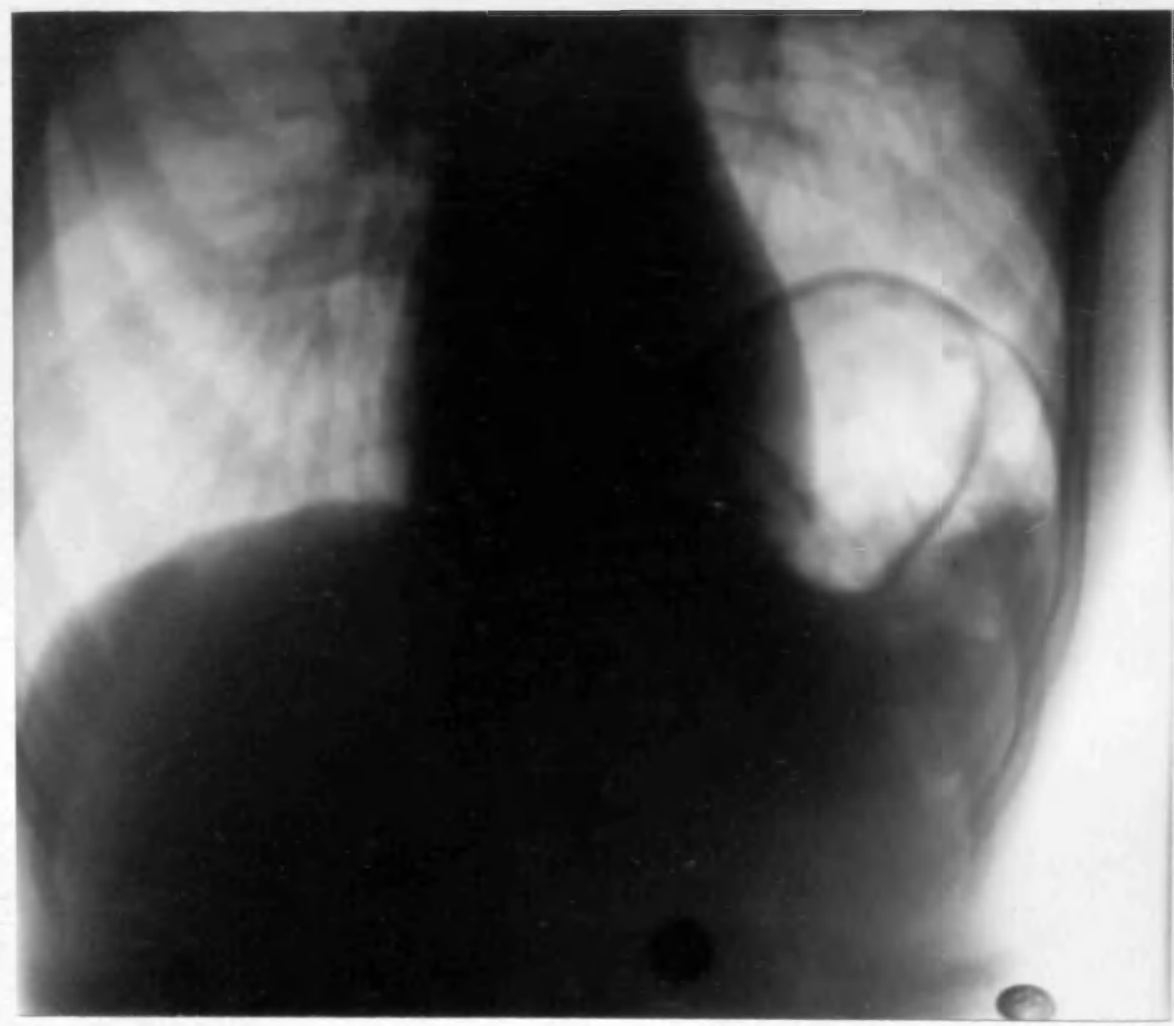

bhest Patrent in lyingdown position Post aut hote bow kive in chest. bolon present. 
Sromp I

base 6.

f. B. male

Eventratio Diaphragmatica.

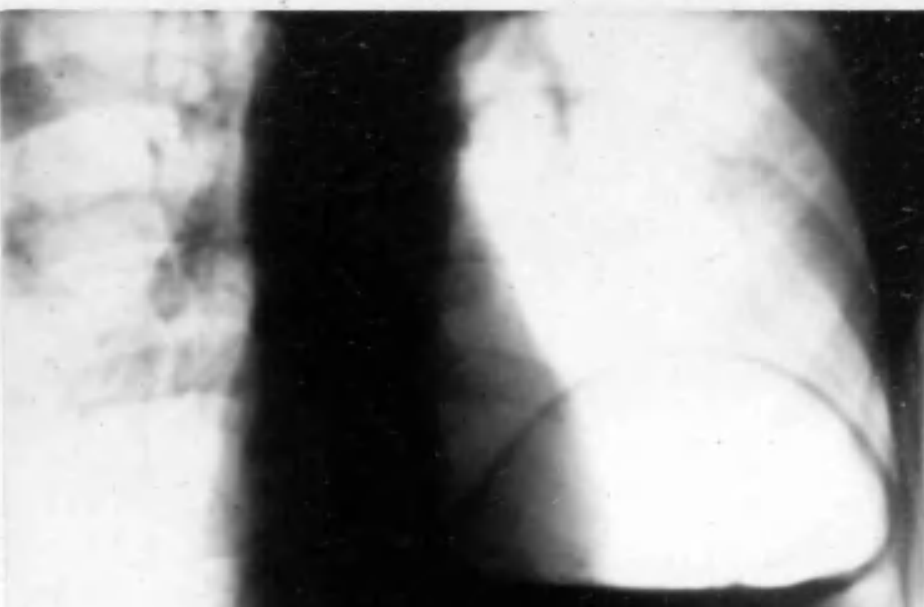

Stomach. Epright position. Post. aut. stomach after bismuth meal 
Plate 22.

Bventratio Diaphragmatic

I roup I

base 6.

1.3. male
aged by year

Stomach Oblique view.

hotedeformily of stomach 
Plate 23

Group I

base 6.

4. B. male
aged st years

Eveutratio Diaphroumatica.

Stomach hyingdown position. slomacn after bromuth meal 
The question of dieplacement of the heart to the right of Eventration of the Diaphragm, large diaphragmatic hernias and in extensive pleural effusions is of interest to the ollclan. Dr. R. J. M. Buohanan, Physician to the Royal Infirmary, Ifverpool, recently showed at the post mortem examination of a case of extensive diaphragmatic hernia, that the apparent displacoment of the heart to the right was in reality a rotation. This is also well seen in the radiograms of cases in whioh large ploural effusions have been replaced by air This leads me to suggest that in Bventration of the Diaphragm the apparent displacement of tho heart is aloo a rotation.

Another question of interest is the movements of the ohest walls. In the ceses I have recorded, nel ther clinically nor under X-ray examination oould any difference in the morements of the ribs on the two sides be detected. This observation also applies to those cases of Unilateral Phrenio Paralyols which are describod in group 2.

Moreover I have noted that the upward and outward morements of the lower ribs tend to flatten a completely paralgeed diaphragm in which reversed movements are taking placo. 
Plate $2 \mathrm{~d}$.

$R$.

h.

Large pleural effusion - left side - edge of which extends beyond the middle live. The heart is shown on the right side rotation of heart. The electro-cardlografohic tracings were so rue al. bot the displacement of the trachea and of the oesophagus, iuwhech there is a lite bismuth food. 
Peate 25

$R$.

$<$.

The same case as Plate 2ds after air replacencut of fluid. 
It is diffionlt to reconolie these observations with the statements in the text booke of anatomy, where we are taught that one of the principal actions of the diaphragm is to ralse the six lower ribs in the act of inspiration. 


\section{Onilateral Phrento Paralyeis.}

It is stated in Oppenheim's text book of Nervous Diseases 1911. Vol. 1. p. 423, that "paralysis of the nerve is not common", and that "a unilateral phrenio paralyeis is difficult to reoognise as the functional disorder 18 very slight . It can useally be detected by careful exemination. Absence of the so-colled "diaphragmatio sign" (Litten) 1.e. the visible movements of the diaphragm accompanying inspiration and expiration, may be of assistance in diagnosing a unilateral or bilateral phronio paralyeis".

I think it will now be generally admitted that unilateral phrenic paralysis is not uncommon. It is - condition which can be definitely diagnosed radiologically. Within the last two yeare I have soen 9 caser, and in two of these cases I was able to confirm the disgnosis post mortem.

In two of the cases the right phrenic nerve was involved, and in seren of them it was the loft. Three of the cases occurred in secondary carcinoma of the mediastinum. One of these cases was secondary to carcinoma of the stomach and the other two were secondary to carcinoma of the breast. 
of the remaining cases three were assoolated with pulmonary tuberculosis, two with growth in the chest and one with aneurysm of the aorta.

In all these cases the diaphragm movements on the affocted side were reversed, and some of them presented the tfpical pioture desoribed under the heading "Eventrat10 Diaphragmatican. Others were complioated by the involvement of the lung in the disease, but my diagnosis of paralysis roated on (1) The elovatid aiaphragm which presented an unbroken bow line in the chest, (2) The presence of reversed movements.

I was ablo to obtain post mortom examinations in two of the cases. In one case the phrenic nerve was involved in a cancer nodule as it crossed the root of the left lung, a section of the nerve below this area showed oomplete degeneration, whilst a eotion of the diaphragm showed degeneration of the musole flbres, but the ahanges in the musele of the diaphragm were not so advanced as one would have expected.

In the eecond post mortem the phrenic nerve was involved close to the diaphragm, and agein degeneration of the muscle was not so extensive as one would expeot. This suggests some auxilliary innervation of the diaphragm, and in the dissecting room, branches of the 
intercostal nerves oan be traoed into the diaphragm mascle.

I "It is sometimes said to receive flbres from the lower thoracio nerves".

I Cunningham's Text Book of Anatomy. 4th. Bdition. p.474. 
Plate 26.

Unilateral Phrenic Paralysis.

Group II

base \%

W. S. male aged g years.

Chest Upright position. Post. ant.

Tuberculosis with paralysis of the left diaphragm. 


\section{Unilateral Phrenic Paralysis.}

Group. 2.

Case 1. W.S. Malo. Aged 58.

This man was suffering from bronchitis and pulmonary tuberculosis. It the X-ray examination I noted very definite reversed movements of the left diaphragm, and on the strength of the reverse movemente, I was able to make a definite diagnosis of paralyais of the left diaphragm due to involvement of the phrenie nerve.

Post mortem, it was found that the left phrenic nerve was involved in a mass of flbrous tissue throughout a distance of 2t inches. There was atrophy of the muscle of the diaphragm on the affected side.

Cese 2. H. I. Male. Aged 50.

In this case there was a definite intra thoracio growth, with complete recurrent laryngeal nerve peley. The soreen examination showed a moderate degree of elevation of the left diaphragm, w th complete reversed movemente; it conformed in all respects with the radiological signs described under eventration of the diaphragm. 
Peate $2 \%$

Enilateral Phrenic Paralysis.

Sroup II.

base 2.

L. male.

aged soyeans

bhest. Syright position. Post aut. Intrathoracic grouth with paralysies of the left diaphragm. 
This was a case of secondary carolnoma of the mediastinal glands, 10 montha after a radical operation for cancer of the breast. The soreon examination showed marked onlargement of glands in the posterior modiastinum and infiltration of a portion of the lower lobe of the left ling, just above the diaphragm. The diaphragm was only slightly raised, and its movements were limited they were very definitely revereed.

Case 4. C.P. Malo. Aged 54.

A case of intra thoracic growth, causing paralysis of the right phrenic nerve with reversed movements of the right diaphragm. The right diaphragm was slightly elevated, but not markediy so, excopt on deep inspiration.

Case 5. Mrs. B. Female. Aged 45.

A case of secondary mediastinal carcinoma, threo jears after removal of the left breast. The left dephragm was elevated, giving the typical bow line in the chest - its movements were reversed, and all the eigns present described under erentration.

Case 6. B. 0 . Malo. Aged 47.

A case of tuberculosis of the right root and upper. 
Plate 28 .

unilateral Phrenic Paralysis.

Group II

base. 3.

A. S. Female
aged 52 years

brest. Upright position. Post act.

Secondary carcinoma with paralysis of the diaphragm. 
Plate 29.

Unilateral Phrenic Paralysis.

Group II

base. 4.

b.9. male

aged s's years.

best Upright position. Post out.

intrathoracic grout h with paralysis of the right diaphragm. 
Peate 30

Inilateral Phronic Paralysis.

Iroup II

tases.

Ins. B. Female aged ks: yeans.

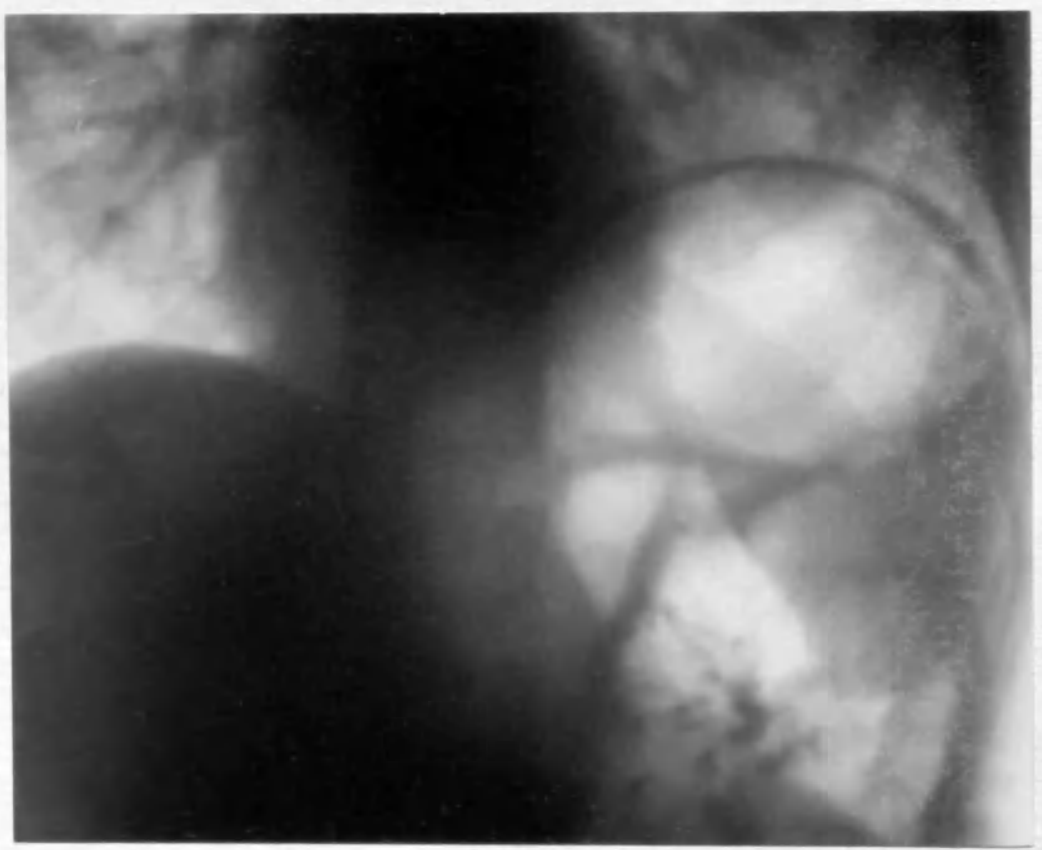

bhest Epright position. Post aut. Secondary carinoma with paralyais of the left diaphragm. 
lobe in whioh there was paralysis of the right diephragm with typical reversed morements.

Case 7.

$$
\text { A. M. }
$$

Male. Aged 56 .

A typical case of carcinoma of the stomach in which there was secondary involvement of the medistinal glands, and invasion of the base of the left lung. The left diaphragm was paralysed, 1 ts movements being reversed. There was very little elevation on acoount of the consolidated lung tissue. Post mortem, the phrenic nerve was found to be involved in a nodule of cancer just below the root of the left lung. His to logieal preparations of the nerve showed complete degeneration, and sections of the diaphragm of the affected side showed marked degeneration of muscle flbre, though not 80 marked as one would have expected from the condition of the nerve, thys suggesting that there is some additional innervation of the diaphragm, presumably from the lower thoracio nerves. 
Plate 31.

Unilateral Phrenic Paralysis.

Group II

base. $\%$

A. In male.

brest. upright position. Post out.

Secondary carcinoma with paralysis of the left diaphragm. 
Case 8.

A. G. Male.

Aged 59.

\section{Aneurysm of the Aorta.}

Clinically all the physioal signs of aneurysm of the arch of the aorta were present in this case, and the X-ray examination confirmed the dagnosis. To the left of the aortio arch a shadow could be sean with an irregular edge epreading downwards to the root of the left lung. The left diaphragm was elevated and the movements reversed. In this case there was ovidently paralyeis of the left phrenic nerve associated with aneurysm.

Case 9.

$$
\text { W.S. }
$$
Male. Aged 52.

There was extensive tuberoulosis of the left lung, and to a lesser extent of the right. The left diaphragm was elevated and partially fixed. Very elight reversed movements were observed. 
Peate 32 .

Anilateral Phrenic Paralysis.

Group II

base. 8

A. male ayed sig. years.

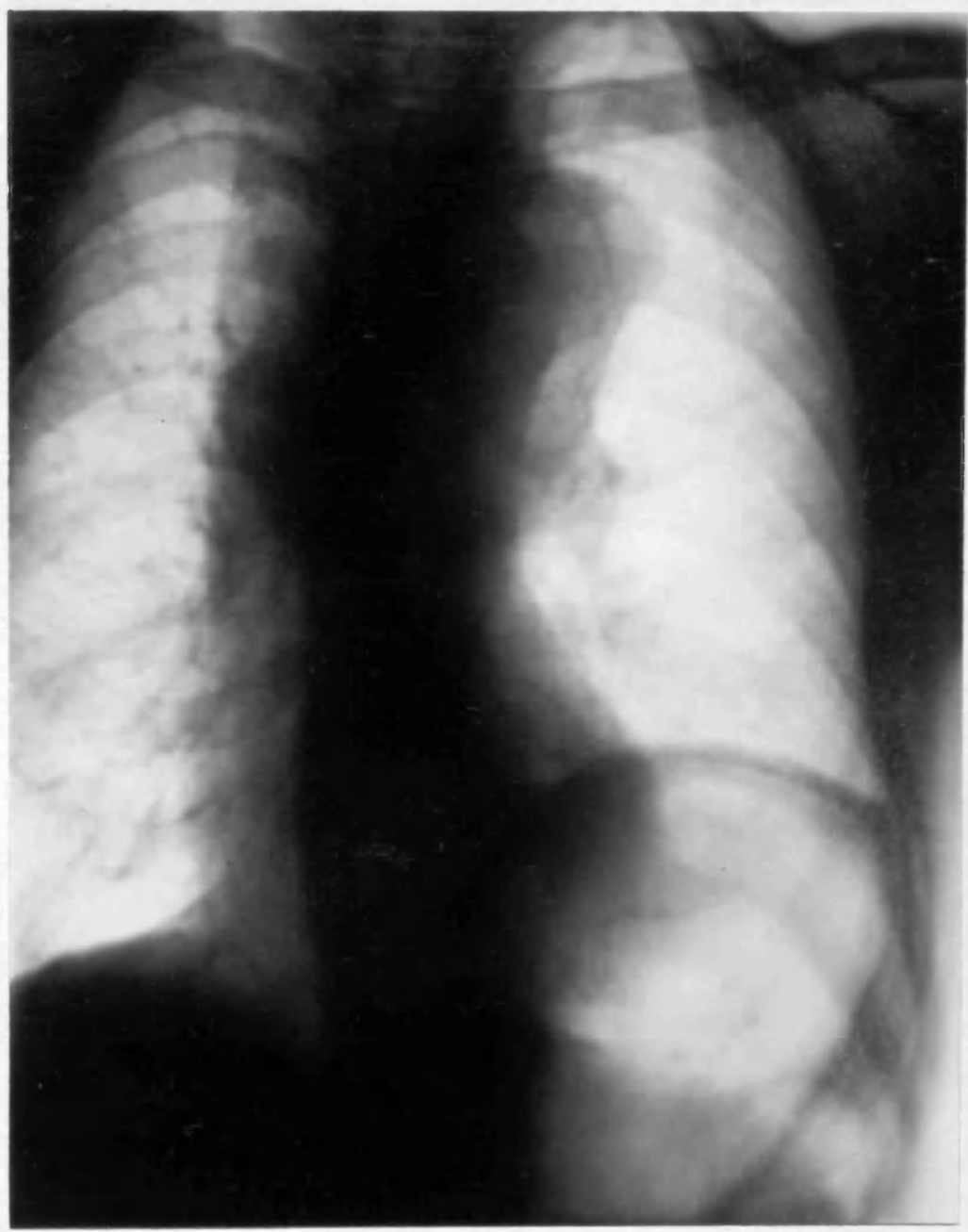

Aneuryom of the Anta.

bhest supright position. Post aut. Aneurypm of the aorta with paralyois of the left diaphragm. 
Plate 33

unilateral Phrenic Paralysis.

Group. II

base. 9 .

W.S. male
aged 52 years

Chest upright position. Post aet. Old standing tuberculosis with paralysis of the left diaphragm 
I was able reoontly to observe the action of the daphragm in a oase in whloh the loft loaflot had been Injured. The patient was a man, aged 31. During the war, In 1916, ho was wound od by an explosive bullet whloh tore its way through the left side of the abdomon and chest. The lower ribs were out tbrough and portions miseing. This resulted in a bornle of the splenio flexure of the colon through the ohest wall on the left s1de. He woars an aluminium pad, ouffers littlo inoonvenienoe and 1o in full work as a manal labouror.

On soroen oxamination the moroments of thosloaflet of the diaphreg were restrloted but the ohost wall was moring quite well and the polnt of speolel interest was that during inspiration, when the diaphragm desoended, the hornia oould be soen retarning to tho abdomen and during expiration when the diaphragm asoended the hernia protruded beyond the ribs. I oen oply attribute this to a defotive diephregm morement, wh1let the moremonts of the ribe during insplration and explration wore normal. I think the prinolpal aotion of the diaphragn 18 to inorease, by 1te oontreotion, the vertios d lameter of the thorax, and cortalnig the rertebral portion of the diaphragm arlalng from the arouate 11gaments and the bod108 of the lumbar vertebrae oan only have th10 effeot. 
hrale, aged 3igean

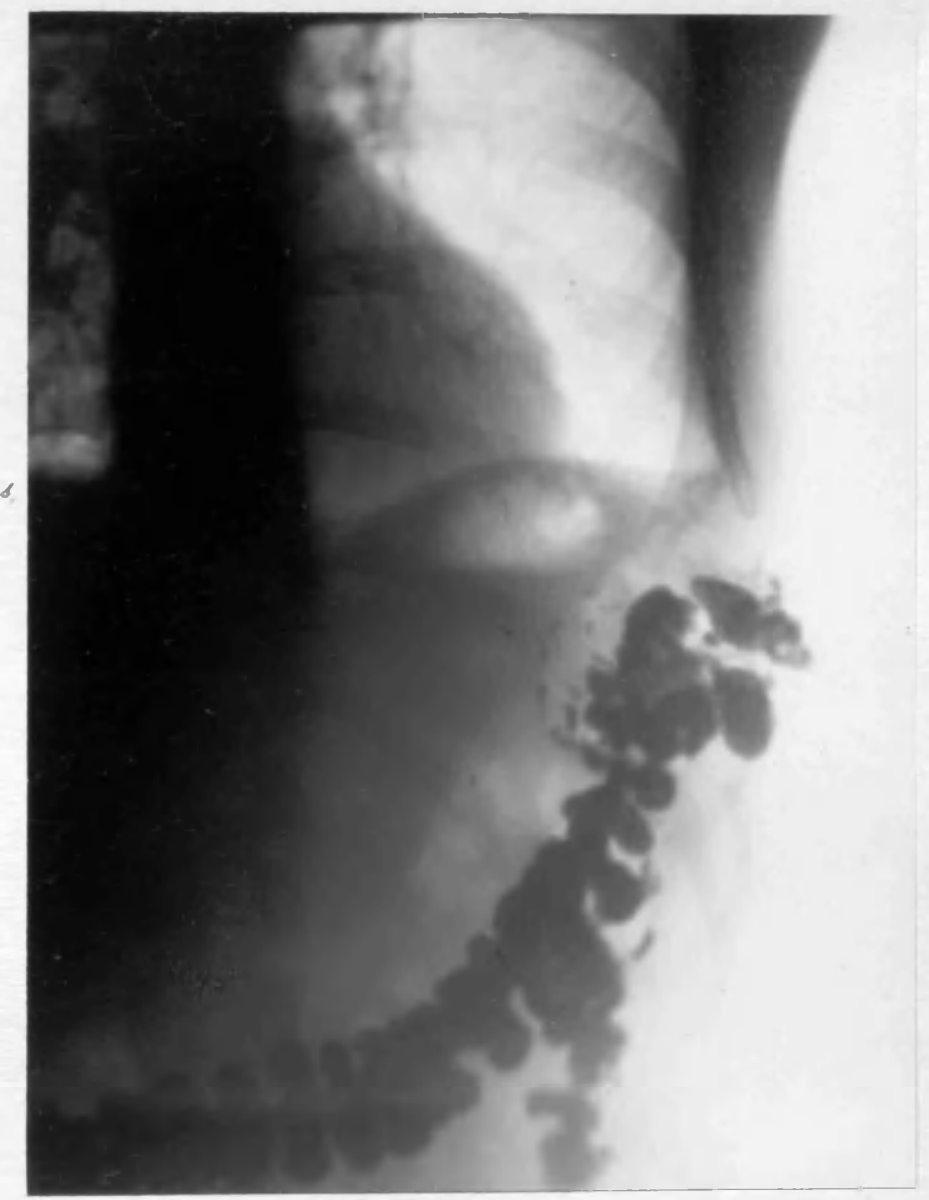

bolon. Gunshot injury to leftside with hernia of the splevic flaxuse. 
Slate 3 Ha.

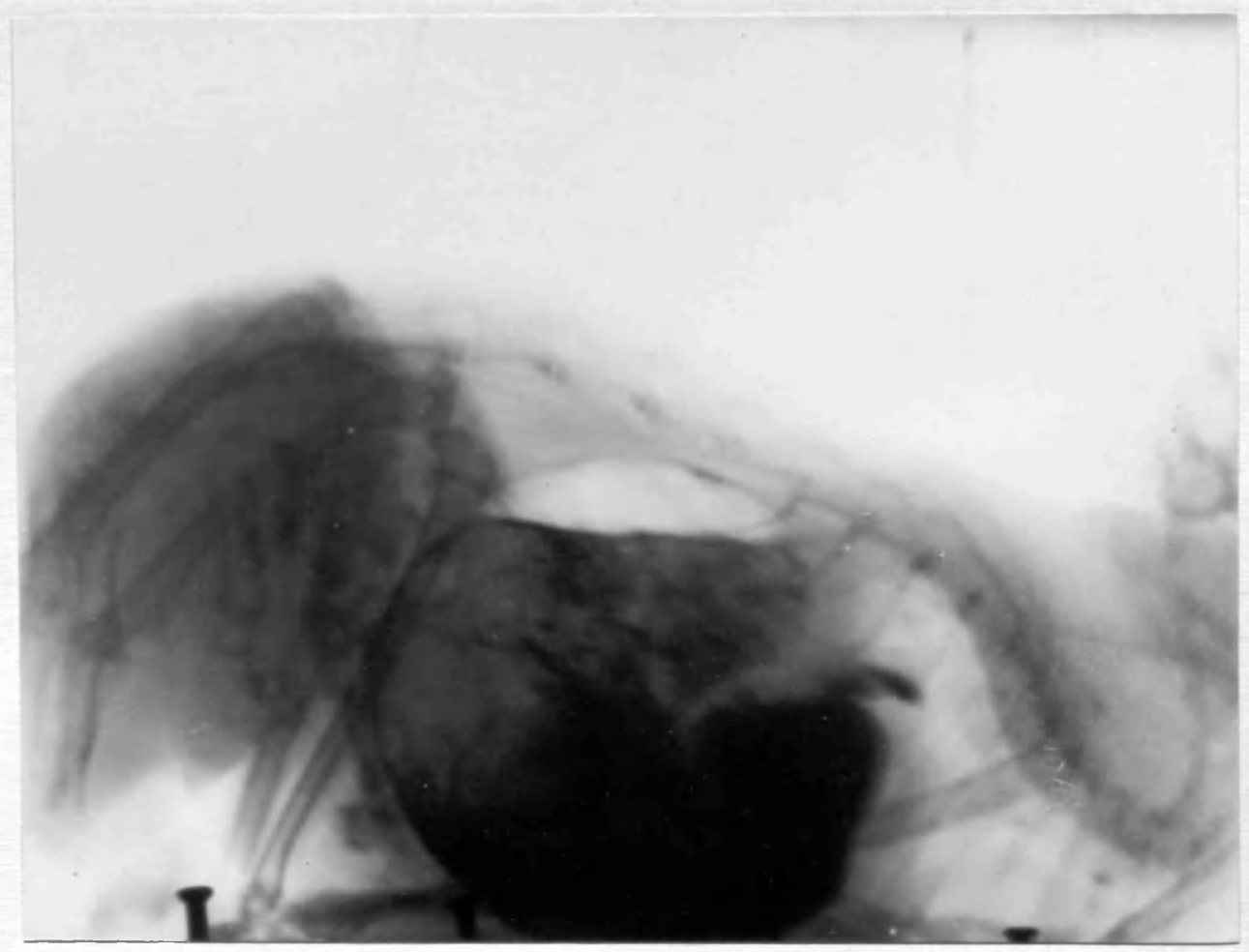

Pabbit - after Besmuth meal. hote ais cap of stomach 
It should be remombered that the contrel tendon oan bo soen to sove slightly downard during o soreon examination of the ohest. The downward thrust of the diephragm on the right side depresses the 1170r oto., but on the left s1de tho alr oap of the stomen aots as a buffer taking up the foroe of the dephragm movement. The stomach during an X-ray examination oan be seen to slter in abape with the action of reapiration. During inopiration it bocomes shorter and broad or, but the loweat part of the greater ourvatare does not alter in position. Th1s holds good in whateror position the body 18 placed. although the air in the stomach way not be immediately und or the d laphragm. In some of the lower animals, 0.8. the dog, oat, rabbit, the alr 880 does not 110 1mod lately und or the dephragm but it can be seen to take up the thrust of the alaphragm by 1 ts olast101ty. The air in the stomeah 18 oomposed of stmopherio air gwallowed in taking food. All this, of course, refors only to the normel.

Thus the radiologloal atrdy of the daphragm tond a to throw some doubt on the teaching in the text books of anatom. that one of the prinolpal actions of the diaphragen 18 to ralse the glx lower ribs in the aot of insp 1 ration.

In considering the caseg of Unllateral Phrenio 
Parelge1s (Group 2) the many points of resemblanoe to Pet 1t' a eventration (group 1) are apparent, 0.8. tho elevation of the dephragm presenting an unbroken bow Iine in the ohest, the presenoe of reversed morements, and in some osses, the deformity of the stomach oto. The thought naturally arose, Could some of the osses of eventration be due to an injury to the phronio nerve at birth jost as the braohial plexus 18 somotimes Ingured? We are all famliar with birth pals108. I heve looked for such oeses, but unsuocessfully. Turning to the ilterature of the bjoot, howerer. I found an excellent acoount by Welgert, of an infury to the left phronio nerve at birth with paralyals of the left leaplet of the diaphragm.

I sholl return to this subjoot in disouseing tho question of act1010Bg. 


\section{Temporary Eleration of the Dlaphragm.}

Th1s frequentig ooours and 18 cansed by geseous distension of the air seo of the stomeoh.

In ohildren it 18 quite comon to see the left dephragu raloed well ap into the thorax and to elnd on the following as that it 18 quite normal in position.

In edults it is often present in pathologioal oonditions of the stomeah - pertionlariy in oeroinoma. It 18 ugualig assoolated with the "oup and op111" type of a stomaoh.

In all c8ses of temporary gleration whioh I have obeerved, the movemonts of the elevated daphragn have boen gymohronous with those of the other half, never reversed. In other words thore has been no peralysis.

\section{GROUR 3.}

\section{Cese 1.}

A case of Temporary eleretion in a child of 5 jeara of age. On the following day it was quite normal. All the uenal radiologioal of gas of eleretion were present but the morements of the bow line were synohronous With those of the other half of the diaphragm.

Cese 2.

$$
\text { E.P. }
$$
Male. Aged 60.

A o8ze of oeroinome of the pylorio ond of the etomach. 
Peate 35

temporary blevation of the Diaphragm.

Iroup III

base. 1

bhild aged syears

bhest. Sypright position. Post aut 
Plate 36

Temporary Elevation of the Diaphragm.

Group III

base. I.

build aged s years.

Same case as Plate 35 taken on following day 
The left diaphragn was elorated but the morements wero regular and in unison with those of the right. Tho Bt omach was of the oasoade tgpe.

Qase 3. B.D. Yalo. Abed 30.

The left dlaphrag was olovated bat great distention of the alr 880 of the stomech was present. The stomech was deformed but no defint to pathologioel lesion was detected. There was no paralyola of the diaphragm, the morements of the two loaflets were syohronous. 
Plate 37

Temporary Elevation of the Diaphragm.

Group III

base. 2.

H. (.) male aged bo years.

Stomach. Carcinoma of Pylons with temporary elevation of diaphragm and deformity of stomach 
Plate 38

temporary Elevation of the Diaphragm.

Group III

base 3.

R.D. male aged so years.

Stomach. Upright pristion. Post out. temporary elevation of diaphragm with deformity of stomach 


\section{Differential Diapoeis.}

The difforential diagnosis of Potit'o orontration and an1lateral phrento paralyals from othor diaphagmatio oondition has now to be considered: They have to be difforontiatod from

1. Dlaphregmet 10 hernia - oongen1tel or aoquired.

2. Loosilsed hydro or pyo-pnoumothorax.

3. Sab-phren 10 absoosa.

4. Temporary elevation of tho a laphragm.

Dlaphragmat1o hernia may be oongenltal or aoquired, and the oongonital defoots in the diaphragm wore thoroughly Investigated by S1r Artbur gelth and reoorded in the Britleh Modicel Journal Ootober 29th, 1910. If h1s d lagram is taken in confunotion with another digram by Broman, representing the dovelopment of the diaphragm, It 18 at onoe soon how these cases oocur. So far I here not had the opportanity of observing this type of oase. I underatand, howoror, that they are not uncomon. Dr. Campbell sattlo of the Royal Hoopltal for siok Childron, Glasgow, In writing to me states that this lo ble oplnion. Ho has seon 30880 within two gears.

A oopgenitel weakness howorer, may ex18t during 11fo, Inviting a hernia, and in one 0280 whloh I record a large 
Claphragmatio hern1e ooourred without any definlte trauma. (Oroup IV. Case 1).

In diephragatio hernie wo ploce those coses in whioh thore is a prolapee of visoore into the pleurel oav1ty through a gap in tho dephragn. Tho X-Ray examinetion shows an elevated irregular broken line extending acrose the hemi-thorax which oan hardig be miataken for the diaphragm. Irong tiasue may or may not be seen through the air und erneath th 18 11ne: the fluid contents meg reach hlgh above the level of the oard180 orifloo, and rippling on the surfaco 18 easily produced by palpation of the abdomen. If the hernis be all one, 28 in cage 2 (Group IV), the reversod morements of the herais during reaplration are well seon, but if the hernis be extensivo, as in oase 1, no morements mag teke pleoe.

The presence or absence of the oolon has also been stresed as a d lognostio point. In oventration it mag be absent or present on different examinations of the same patient. In hernis the same obeorvation holds food, although it is praotioelly alweys present at operation, but thon the oond lions heve boen altered by the opening of the abdomen or obest, the opening In the diaphragm appoaring wach larger than the $x-R a y$ examination would loed one to expot. 
The examination of the atomach by means of a blamtb mosi 18 of the groatest importanoe and abould rarely fall to sottio the diagnosis.

34. 
Plate 39

Sroup IV

basel.

I6. male

ajed 26 years

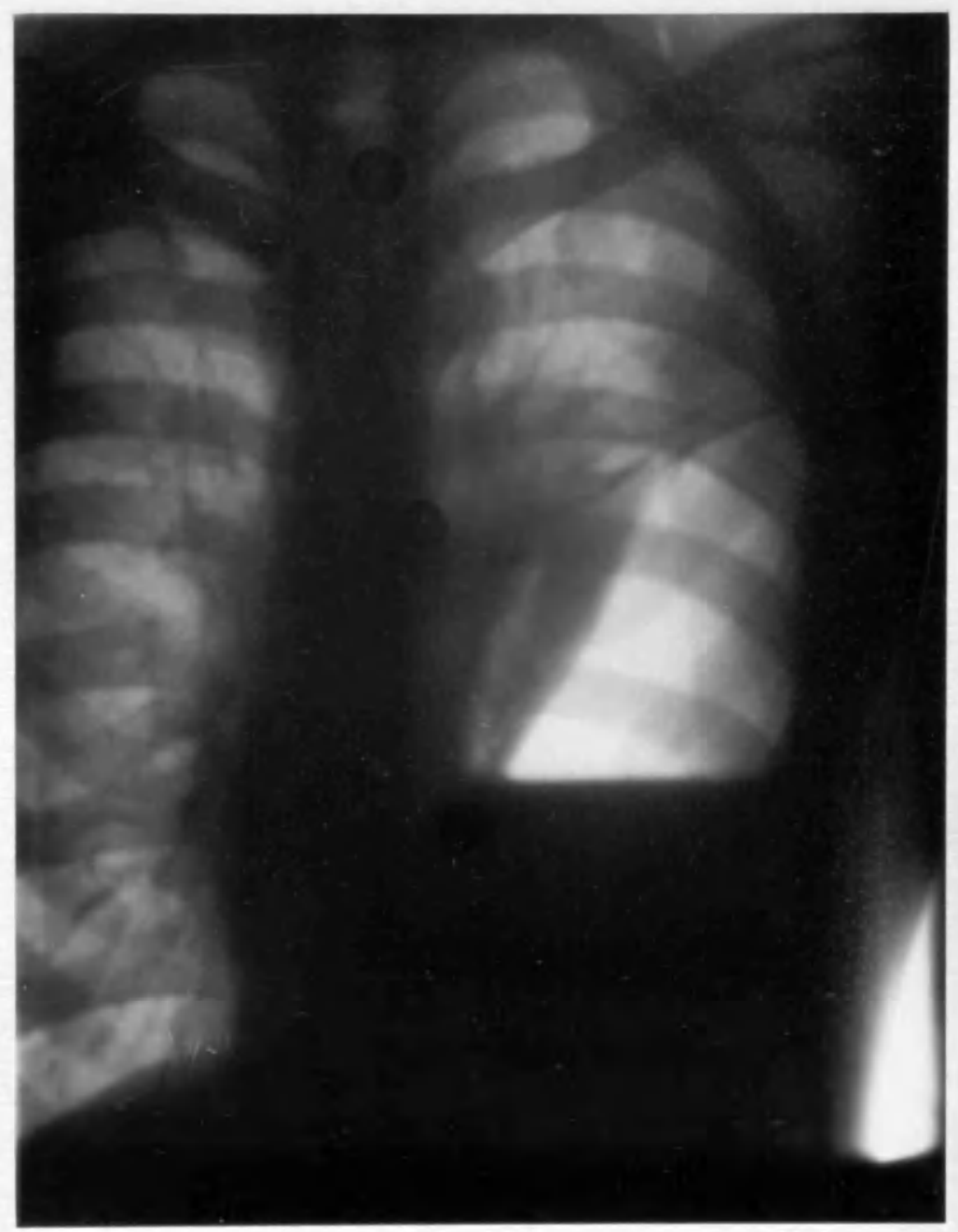

bhest. Epright position. Post aut. harge diaphragmatue hernia. The colon isnotpresent. as a part of the hermia. She X-Ray appearauces are those of hydropreumothoraxe. 
Plate 40

Group IV

base. 1.

I6. D. male aged 26 yeans.

brest typright position. Post. ant. Same case as Plate 39. on the following day. bevel of the fluid. This was the diagnostic e 


\section{Peate dil.}

lroup IV

lone 1.

\%.9. male

aged 26 years.

bhest. hying down position. Posh aut. Same case as Plates 39 × 40 


\section{Diaphrapat 10 Berniae.}

Looal 1sed Braro or propneren thorex.

Sab-phren 10 abocens.

gRour 4.

Qane 1. H.W. Hal0. ABed 26.

There was no hlotory of ang injury. The physioal examination gave all the signs of a hydro-pnoumothorax. The soroen examination showed the dark lino of fluid extend Ing right aorogs the loft obeat with o olear air

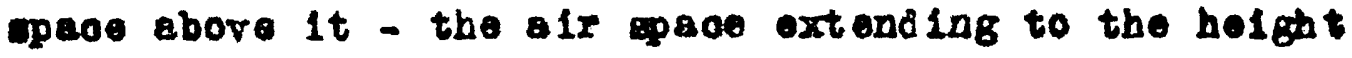
of the and. rib in sront, the fluld to that of the 4 th. A portion of oollapsed lung was noted through this oloar air op806. No lung tiacue was seon apart from the collapeod lung. There was no definite bow line obeerved and no paradoxiond resplratory movements.

Palpat ion of the abdomen produoed ripples on tho arface of the fla1d. The appoaranoes were quite oonalatent and, In faot typlosi of a hydro-pnoumothorax. Lt a later exsmination howovor, the aplenic flexure was ooon rialng up elongeide the fluld to a holght, if any. th ins. ellohtly aboro 1 t.

At operation 1t was found thet there was a large rent in tho posterior wall of the diaphrage and that preotlosily the whole of the stomach and a largo portion 
of the 0010n were in the cheat.

Qene 2.

J.S. Hale. Ared 40.

Phis was definite oase of hernia of the left

loaplet of the diephregm, due to a gunshot wound. The X-ray cocanlation ahowed an 1 rregular 11 ine in the left oheet, the inner portion of this irregular 11 ine bolng dephrage - tho outer part stomsob. The morements were vary plainiy seen on the goreen and ono could ace tho laner half moving commarde whllo tho outer hall movod upwardo. Tho blomatb moal axamination very definitely eatablished the diagnosis, for with tho patient in the Iying down position ono was able to ran the blemth beokwards and forwards through the opening In the Giaphrage asd watoh the horniated portion of the stomah flliling and emptying. This wag done by tilt. Ing the tablo top during the exanination.

The epproximato olse and pooltion of the tear in tho dephragm was asoortalned, and it is intereating to note that the oolon was not seon forming part of the horria during the $\mathrm{X}$ atiag axeminetion.

At the operetion by Kr. L. B. Burgeas, F.R.C.S., the abdowed was openod and it was found thet the outor and pottorior part of the diaphreg had beon torn from 1to strohments. Both otomah and oolon formod part 
Plate tr 2.

Group IV

Case 2

ISS. male
aged wo years.

Diaphragmatic hernia. Upright position after a bismuth meal. Rote the irregular bow live 
Plate 43.

Sroup IV

base 2.

f. S. male
ajed. Ho years

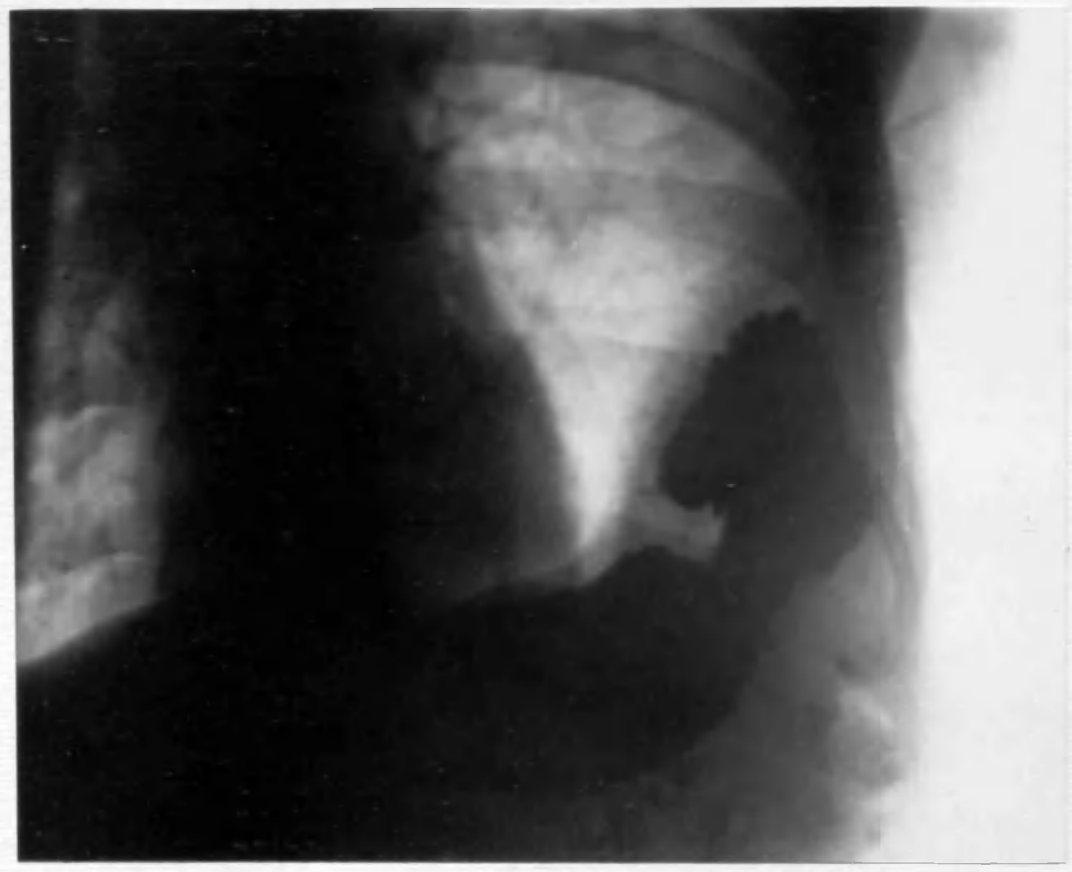

Same case as Plate 43 . Lying down position. kote the herniated stomach outliced by bismuth. 


\section{Plate dide.}

Group iv

base 2 .

L.S. male
aged. koyeass.

Same case as Plates 42 r 43 . Lying down forsetion afier peration 
of the hernia.

The A laphragen waw ropairod and later on $\mathrm{I}-\mathrm{rag}$ examination abowed the result to be oxooliont.

Cage 3. T.B. Haze. Asod 30.

Eexnle of the right a lephrarm, doe to a ganghot wound - Branoe 1914. 2ho right d laphragm was f1xed bat the I1ror ghadow was seun elevated - reversed moromente.

Cege 4. Q121. $\triangle$ sed 13.

Iooalleed Hydro-pneapothorex. Th18 oese wao soen one yoar after operation for expyome. The girl was in exooliont boelth and dolng 11 ght house work. There wan a local180d hydro-pneunothorax present. The IIne of elaid wes ebove the lerel of the card 180 orifles and each heart beat produoed wares al ong the eurface of the IIn1d.

Who position of the diaphrage was easily esoertainod by gdag a nalits powder.

Qege 5. G.0. Ged 16.

sab-phrea10 Absoege, In this o8Be a abb-phron10 ebsoens developed three weeks aftor operation for eovte append101t18. The epponitx was retro-obecel and gangronous and an absoess wa present whlob was dralned. Furthor trouble developed, howerer, and at the X-Ray 
Group Tr

base 3.

I. B. male

ayed so yeans

bhest. spright position. Post. aut. Hernia of the night Diaphragm 
Sroup IV

base 4.

Gint ayed isyans

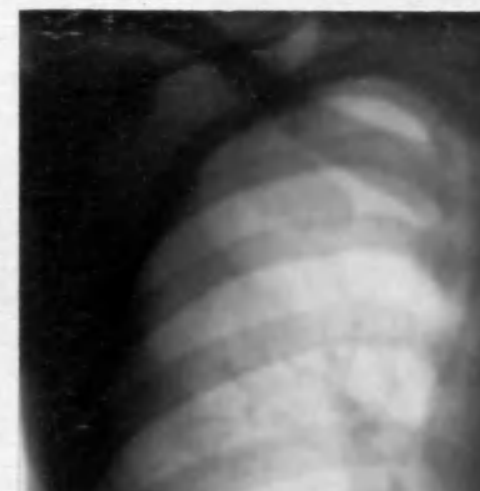

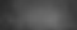

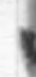

bhest. Sprightposition. Post aut. $L$ ocalised $l o$ ydro-pneumothonax 
Plate $4 \%$

Group IV

base 5.

to apdoloyenc

Sub-phrenic Abscess S Spright posetion 
Plate 48 .

Gnoup iv

base 5.

6.0. aged Itoyans

Sub-phnenie abseess. Lyuig down posetion 
canination the right diephragm was Iound oloreted and elxed. With a olear air ggaoe underneath, at the lower border of whioh we atrelght line of free Iluld. 3plashing of the Imale wadeseliy produoed, and in the Iy Ing down poeltion the eir was diaplaced, the Iluid ranning up into the obest to the level of the bor $11 n$. The lower wargin of the 117er wa puahed downarda.

A Iurther operation was done and a eab-phren10 absoegs we.8 found containing large quantity of loulgmoling pre.

Care 6.

$$
\text { W.S. }
$$

Nole.

$\operatorname{sed} 33$.

sab-hepat10 Absoess. On 82.2.23. this nan was oporated on the Manohester Boyal Infirmary for an conte eppondix. A perforeted appopdix wes found with the prosenoe of an absoese. He progreseod quite cat 1ufeotory and was disoharged on 26.3 .23 . Bo was re-edmitted on 18.4.23. and the X-Fay examination chowed oloration of the right diephragm and I1ver. There was no Iluid doteoted and no eoperation of the alaphrage Iron the 1170r. Ho noromote of the elerated a lephraen and Iiver were doteoted.

It the operation a large oub-hopatio abouege was lound end Arained. 
Peate 49

Gnoup iv

base 6.

W.S. male ayed 33 years

Sub-hepatio abseess 


\section{AETIOIOGY AID II FERATORS.}

The uevel statement found in the 11 terature 18 that the aet1010Bg 18 ot1 11 obsours. Pet1t rogarded the oondition a belne of congenital orlein.

Yost of the cases rocorded have been in adults, but there 10 one case of an autopey of a footue in which orentration of the left diaphragm was found. Another autopeg of a now bom lofant rerealed a simllar condl tion. These were the oeses of Pyl and kookel, and were quoted by Lasoher.

stoln reoords typioal eventration of the left diephragm in a now born obild whloh lived 26 days.

In this case the left loaflet of the diaphragm wes a thin Ilbrous struoture extending high up into the thorax, with no musoular 11bres.

Thowa laid great atrese on the hypoplasia of the left lang, it having boen often noted at post mortem examinatione that the lower lobo of the loft lune was abnormally buall. Nihon the lung 18 too small the diaphragm Iseo to 1111 the opace in the ploural oavity. drage 1 ag the Intestinal oontents with it".

Dooring put forward tho theory of a oongenital 
deflolenoy of the mue He polnte out the deflolenoy in the magoular t18sue of the affooted loaflot of the diaphragm and the gymotrical conaltion of the thorex. The woak diaphragm fallo to expand the lung, and aseumes the high position dragglng the risoera with 1 t. This theory 18 not oupported by the post morten exeminatione, as the condition of Atelootade has nover been found. It 18 interesting to note that Thoma, is eupport of his thoory that the lang 18 ohlofly at fault, ol tes the prosenoe of muecular flbres in the diaphragm, whilet Doering of toe the deflolopoy of mueoular t188ue in the diaphragm as a roagon in apport of h18 opinion.

Baetse rogarded it as dovelopmental, wh1lst Vogel thought there was a congenital prodisposition of th degenerative ohanges in the musoular 11 bres.

Wotsleldt thought it due to:

(1) Primary aplasia of the musonlature with 8000ndary atrophy and degeneration of the phren 10 nerve.

(2) Primary aplasia and atrophy of the phronio nerve with seoondary musole degeneration.

(3) A combination of (1) and (2).

Tonpant rooordod quil to a unlque oase of a man - aged 60 Lio. 
He found post morten the anterior one-third of the left leaflet of the diaphragm normal, but marked off bohind Irom the rest by a band extended from the 10th. 008 tal cartilage to the oentral tendon - the posterior two-thirds of the vanit was lax. Ilabby and puehed up towards the neok in the form of a large pouch which contal ned a large ompty atomach and part of the transierse colon. The loft orus and remal nder of the diaphragm were normal, as were also the lungs and heart. The left phrenic nerre was examined mlcroscoploally, bat the eoction did not ohow ang abnormality. There was nothing to support the riow that It was cemeed by ang morbld condition of the lunge or ploura. The ohost wer not contraoted. Ho rogarded it as " 10880 of congenital imperfect differentiation of the d1 aphragm".

Lawrence, in 1852 reported a 0880 with the post mortem Il adinge in the Lanoet and this same case 18 agaln roported In the Lanoet by Marah in 1867. It was a typiogl oase of eventration found post morten in a man agod 33 jears who had died of poeumonia. "The left half of the diaphragm was arohed up to the $3 \mathrm{rd}$. Interoostal speoe, and the otomach, whtoh was extromely largo, was pushod ap so hlgh ae to be nearly oonoealed by the riben. The right aldo of the dephragm was normal. The left loaflet wes a 
grey flbrous tranaluoent atruoture with nvery fine ahort otriac of musoular flbres extending from the inner surfaco of the ribs and 11 gamenta arouata for the distance of $6-8$ 11neg". Marah states further the Mr. Pagot thought the dofoot a congenital one" and that "there appeared, notwithotanding thiodefoot, to be ouffiolent regpiratory power. The pati ent breathed very forolbly in his dyspnoea, and in auscultating him the moremente of the oheot appeared just as in an ordinary double pnoumonia. The left side of the ohest oertalnig mored freely, and the patient often lay on the right side".

Sal lor and Rhein desertbed a oase of a farmer aged 20 years in which post mortom a skigram was taken whioh showed an eventration of the left di aphragm. Tho pointe of pote in this case were the displacement of the heart to the right, the presenoe of musoular fibros in the left loaflet and the congenital melformation and hypoplasia of the lung.

Other caseg gimliar to these whioh I have quoted have been reoorded by Thoma, Doering, Crisplno, frorlep, and Widenmann whose c8se was also reported by Glager. In the oase of Widenmann and Glaser it 18 of interest to noto that the pationt euffered from gastrio syoptoms, and on two ooosions haomatemesis oocurred. 
Injuries to the Phrealo nerre mag ooour at birth and reoently Welgert and Kofferath have rocorded caser.

Wolgert's oase was due to tranma during dellvery. The left diaphragm was elevated and all the rad10logloal appearanoes of an oventration present. He observed this cese untl 1 oomplete recovery took plece in the couree of about two monthe. Kofferath desorlber "a o880 of right-81aed Erb paralg818 and paralysis of the phrenlous following foroop dellvery". The X-ray examination showed an abnomelig high position of the right half of the diaphragm. The might half in a totilly abnormal manner; on 1nepiration 1t ro80, and desconded on explration. After four days resplration becamo apperently quite nomal and a later examination ahowed normal conditions.

From the study of my own cases of Brentration and of On1lateral phrenlo paralgeis, along w th those recorded by others. I would suggest that eventration may bo due to two carnes.

(1) A derelopmental defeot in the formation of the musoular tissue of the diaphragm. The diephraem, acooralng to Bromen, 18 thus dortroderom four souroes (I1g.198). (1) Its 
rontro-poricaralal portion from the eoptam tranerereum, Ite lateral portions from (2) plouroperioardial mombranes plas (3) derivatives Irom the body wall. The dorsal portion 18 formed from (4) the dorsal mosentery. In addition to these the Btriated mascle of the diaphragm, acoord-; Ing to Bardon (1900) takes ite origin from a pair of premuscle mas8es whioh in 9mm. ombryos 110 one on oeoh alde opposite the 5th. oerviall segment. This is the level at which the phronic nerve ontere the eeptum trangrersum. The exact origla of these musole masges is in doubt, but they probably a represent portion of the cervicel myotome of thie region. The mukole mageos mygrate caudally with the septum transiersum and dovelop ohlefly in the dorsal portion of the diaphragm.

Embrgology.

Prentios \& Arey. 1980.

(2) An injury at birth to the phroulo nerro. That such infuries do ocour we have soen in the caser rocorded by ivelgert and Kofferath, and I do not think it is too muoh to suggest that the 80 may be the canse of erentrations whioh may peralet th roughout 1110 . 
Plate 50

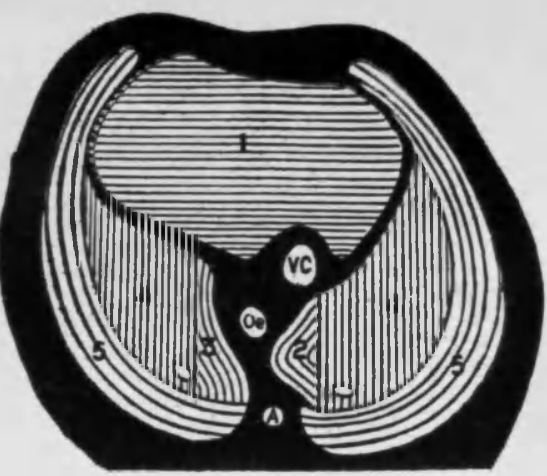

FIG. 198. -Diagram showing the origin of the diaphragm (after Broman). Septum transversum; 2, 3, derivatives mesentery; 4,4 , derivatives of pleuro-peritonal membrane; 5,5 , parts derived from the body wall; $A$, aorta; Oe, esophagus; $V C$, inferior vena cave.

a.

Espied from Iombryoligy - Prentiss y are $3^{\text {sq }}$ edition - 1920

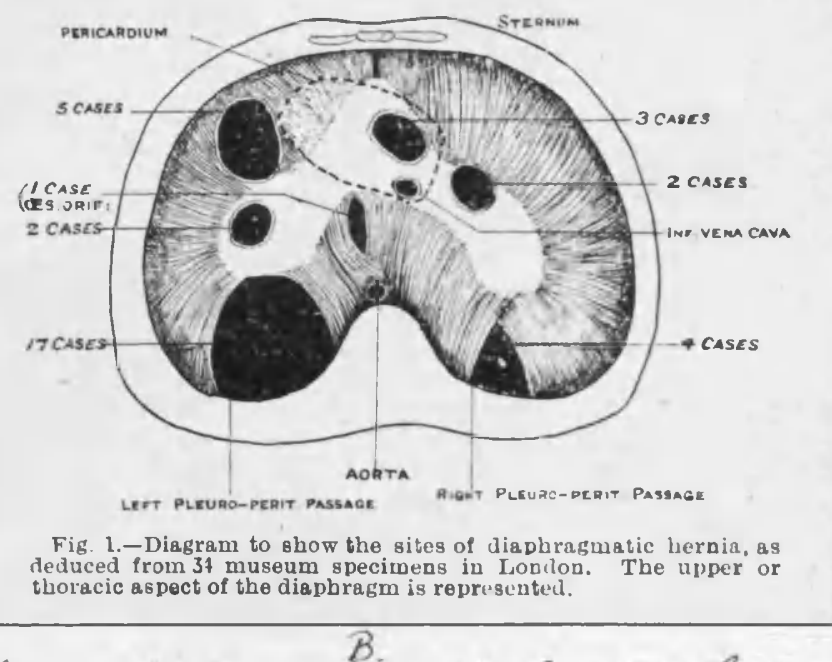

Copied from article by Sir St thur Keith in the British medical formal October 29"t 1910. 
Plate $5 \%$

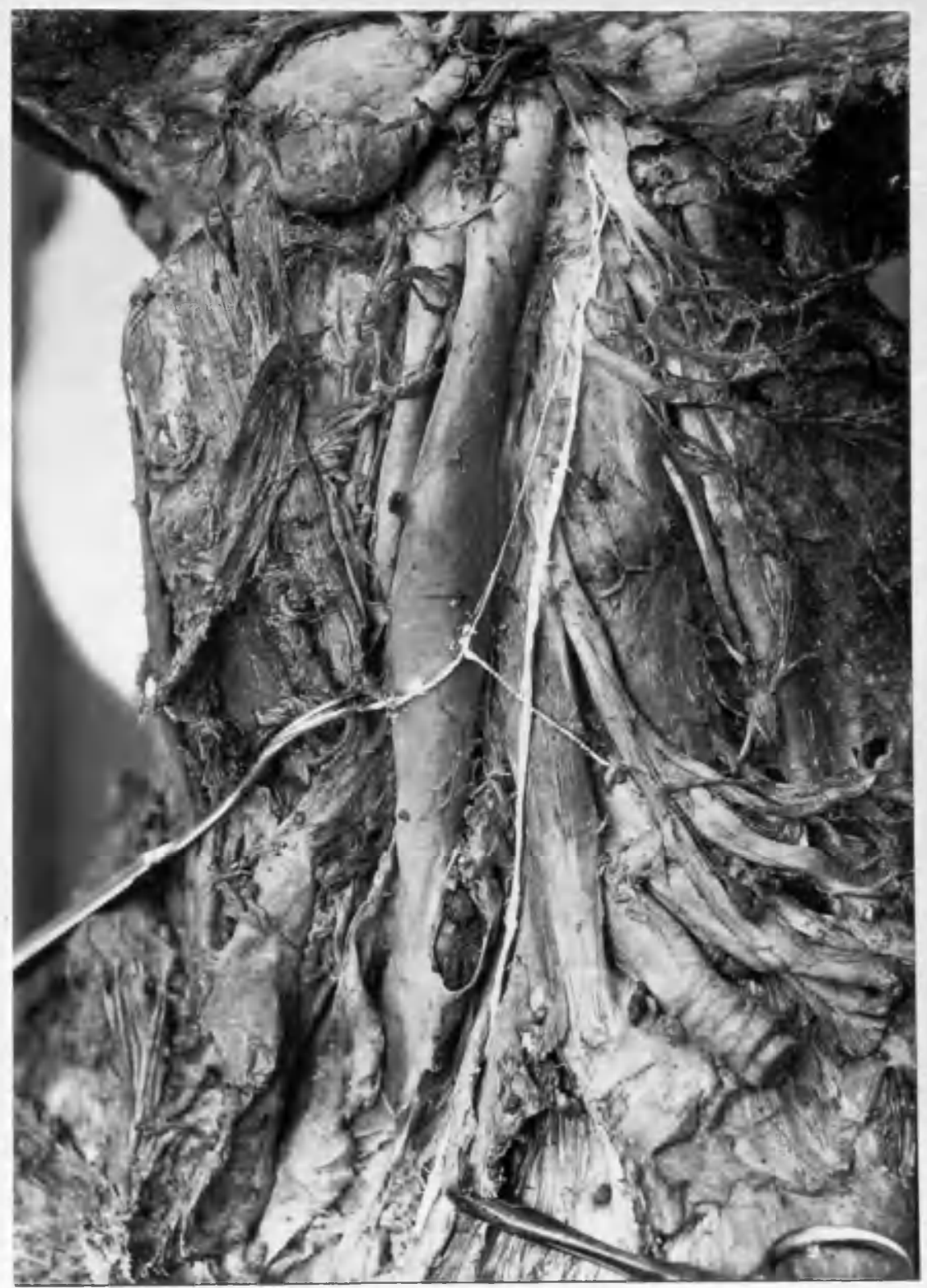

Dissection of neck don in the Auatomy Roomshranchester bnivorsily.

The disceudeus cervices is pulled to one sido by a metal hook, to which an arrow points. The phrenic newe cau be seen rising from the cenvical plexens 3.4.5. in this case 


\section{CONCIUSIONS.}

(1) Petit's Eventratio diaphragmatica and unilateral phrenic paralysis are not so uncomon as is Eenerally supposed. Radiographically they present many similar features.

(2) There is evicience, in a, study of the cases presented, and in the I1terature, that eventration maj be due to:- (a) a developemental ciefect in the muscular tissue of the diaphragm. (b) an injury to the plonenic nerve at birth.

(3) At first it was a pathological study, It is now posaible, with the advancement of racilology, to observe and diagnose these cases during Iife.

(4) Mang of these cases have exhibited gastric symptorns, inci I would draw special attention to the cieformity of the stomach due to mechanical causes which I have described. It should be notec that tisin ieformity maj become a surgical condition.

(5) The differential diagnosis, from the radiological satndpoint, rests mainly on:-

a. the unbroken bow line extending high up into the thorax with its reversed movernents, unless achesions have formed. 
b. the level of the free fluid in the stomach is that of the cardiac orifice. c. the Biamuth meal examination.

(6) The radiographic study of the diaphragm does not support the teaching of the text books of anatomy. that one of its principal functions it to elevate the lower six ribs during inspiration. It rather suggests that the diaphragrn plays little or no part in elevating the lower ribs, and that its principal function is to increase the vertical alaneter of the thorax by its contraction. 


\section{TERA IURE.}

1774. Pot1t.

1780.

1790. mralté de maladies onl rarg. 18t. Ba. $" n " n$ 2nd. Ed.

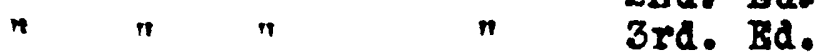
ro 1. 11. p.234.

Posthumous Forks - oollected and -dited by Lespo.

1837. Froriep. Klolnort's Repertorim.

1852. Lawrenoe. Lanoet. vol.11. p.327.

1867. Marah. Lanoot. v01.1. p.898.

1880. Laroher. Doutsohe Arohit. F. klin. Hed. vol.20r11. p.268.

Pyl.
yeakel. Quotad by Iaroher.

1882. Thoma.

V1rohow's Aroh17. V01. 120xv111. p.515.

1887. Kaufmann. Dout. Mod. Wooh. Ho.28.

1894. Tennant. Edíburgh Hedi cal Journal. Julg. p.29.

$1896-1905$.

1898-99. Stockton. Buffalo Medioal Journal. p.97.

1898. BronlB. Contralbl. I. Innore Mod. vol.xix.p.178.

1900. Criaplno. Riforme Medica. \$08.187 - 189.

1902. Wldomann.) Berliner kl1n. Woch. Bo.11.

1903. Glaser. ; Leuteche Aroh1v. 1. kl1n. Hod. rol.lexvil p.370. 
II TERA IURE.

1802. Doer1ng.

Deutsan Archiv. I.KIIn.Mod.vol.12011.

1905. Sa110r.J । Foln, R.D.)

p.407.

Americen Journel Hedical colenoer. v01. 0xख1x. p.688.

\section{$1906-1922$.}

1906. Hildebrand \&) Nunher Med. Woheohr. 111. p.745. He8s.

1908. Arnsperger, B. Deutsohe. Aroh 1V.1.k11n. Mod.xo111. p. 88.

1911. Becker. T. Fortsahr.8.d. Gb.d. Rontgenstr.xण11 p.183.

1911. Epplager. Allg.v.Fpoitelle Path.des Zworchtello.

1912. Sohoidemand el. Manchen Med. Fohnschr. 11x. p.2168.

1912. Giffon. Ann. Surg. Phi lad. 17. p.388.

1913. Baotze. Deuteohe. Arahlv.I.klin.Med. ox. p.49.

1913. Vogel. Amerioan Journel Kod. Solences. oxlv. p. 206 .

1913. Motzieldt. Denseche kod. "ahneonr. $\operatorname{xxx} 1 \times$ p.312.

1913. Reus8. n " " p. 743.

1913. Ma880. Wlen.kl1n. Hohnsahr. xxv1 p. p.193.

1913. Kayer. Fortschr.a.d. Gab.d. ROntgenstrahl. xx. p.240.

1914. Ste1n. surg. Gynaecal. \& abetet. vol.xv111. p. 547 .

1920. Welgert. Beltr.z.kl1n. Ch1 rurpl e.v01.119.p. 100. 1921. Kolforath. Monaterchr.I. Goburtahtilo $\nabla$ Grakol. v01.1v. p.33. 